\title{
LONG-TERM CARE
}

A REGIONAL MODEL FOR RURAL PRINCE EDWARD ISLAND

By Timothy E. Phelan

A thesis submitted to the Faculty of Graduate and Postdoctoral Affairs

in partial fulfillment of the requirements for the degree of

\section{MASTER OF ARCHITECTURE}

Azrieli School of Architecture \& Urbanism

Carleton University

Ottawa, Ontario

(C) 2015

Timothy E. Phelan 


\section{ABSTRACT}

This study investigates and proposes modifications to the present provincial long term care model on Prince Edward Island. From experience as a visitor, present conditions have been defined and dictated by the machines used to service and care for the inhabitant. Lacking in sensory stimulation, the architecture simply becomes the envelope as a means to encase the equipment and secured shelter for the inhabitant. The current model has been designed to encompass larger numbers of individuals which requires the relocation from the normal everyday existence of an individual to something entirely new. The existing model consists of four main Facilities across Prince Edward Island. This thesis investigates the possibility to make revisions to this predominant and current model to 
allow for several smaller rural facilities allowing for the residents to remain within their original communities, lessening the traumatic effects of a transition to an assisted life. Redirecting the focus to rural areas of Prince Edward Island will encourage continual contact between the inhabitant, their family, and their definition of home. Reducing the size of the facility will change the environment from institutional to residential with focus on spatial relationships and incorporating public use into the program. The proposed prototypical model will also allow individuals the ability to remain in their communities promoting a longer, healthier way of life. 


\section{ACKNOWLEDGEMENTS}

First and foremost I would like to thank my thesis advisor, Federica Goffi, for all of your guidance and support throughout my years at Carleton University.

To Yvan Cazabon for encouraging and assisting in my transition to Carleton University.

To the incredible people I have met while attending both my undergraduate and graduate studies. Your support and random design critiques have pushed my creativity and design abilities beyond my expectations.

Finally, I owe my most sincere appreciation to my wife Krista. Your support and encouragement over the past six years allowed me to continue my journey of architectural studies. 


\section{CONTENTS}

Abstract

Acknowledgements

Contents

Thesis Statement

List of Illustrations

1 Long-term Care

1.0 Definition

1

1.1 Forecast

3

1.3 Best Care - Home Care

1.3 Long-term Care - Prince Edward Island

5

1.4 Precedent

1.5 Personal Investigation

2 THE OCCUPANT

2.1 Resident

20

2.2 Visitor

23

2.3 Support Staff 
3 THE PROPOSAL

3.0 Site Analysis

3.1 Concept Design

3.2 Design Precedent

39

3.3 Proposed Facility Design

Alternate Building Section

Conclusion

Bibliography 


\section{STATEMENT}

The design of today's Long Term Care Facility needs to awaken and stimulate the human senses while allowing opportunity for individuals living in the rural communities of Prince Edward Island to remain within their community. Keeping residents anchored to their pre-existing community will encourage the continuation of everyday routine without the need to redefine their place in society. 


\section{LIST OF ILLUSTRATIONS}

Figure 1: Mapping diagram of the four new Long-Term Care facilities across Prince Edward Island.

Figure 2: Prince Edward Home, Charlottetown, Prince Edward Island.

Figure 3: Typical resident unit. Prince Edward Home.

Figure 4: Floor plan of typical unit. Prince Edward Home.

Figure 5: Interior finishes of typical unit. Prince Edward Home.

Figure 6: Macro + Micro site images. The province of Prince Edward Island + Village of Morell.

Figure 7: Micro Site Analysis: Village of Morell. Identification of infrastructure.

Figure 8: Thesis Site Plan. NTS.

Figure 9: Street view of proposed site. Riverside Side Drive, North \& South. Figure 10: Street view of proposed site. Route 2, East.

Figure 11: Site concept sketch.

Figure 12: Site concept sketch.

Figure 13: Regional context of Morell, Prince Edward Island.

Figure 14: Windswept exterior cladding.

Figure 15: Red Head Harbour. Existing building elevation and plan

Figure 16: Cabot Beach Camp Facility. Malpeque, Prince Edward Island. Figure 17: Cabot Beach Camp Facility. Malpeque, Prince Edward Island.

Figure 18: Cabot Beach Camp Facility. Malpeque, Prince Edward Island.

Figure 19: Four elements of building program.

Figure 20: Main floor plan

Figure 21: Key Plan: Art Gallery, Food Prep., Dining Area, Exterior Dining.

Figure 22: Key Plan: West [MAIN] Entrance. Access from street + Water.

Figure 23: Key Plan: Resident Units. Illustrating (gradient in level of care).

Figure 24: Resident Unit Layout. 
Figure 25: Typical Resident Unit. Section A

Figure 26: Typical Resident Unit. Sections B \& C

Figure 27: Interior view of resident unit. (Sleeping area towards living area)

Figure 28: Interior view of resident unit. (Living area towards kitchenette and sleeping area)

Figure 29: Interior view of resident unit. (Kitchenette towards living area and sleeping area)

Figure 30: Key Plan: Resident lounge spaces. Street View + Water View

Figure 31: Key Plan: Nurse Station

Figure 32: Key Plan: Building Services.

Figure 33: Building Perspective (Water Side)

Figure 34: Building Approach (Water Side)

Figure 35: Building Perspective (Resident Unit/Lounge)

Figure 36: Building Section D

Figure 37: Building Section $E$

Figure 38: Alternate Building Section $E$ 


\section{LONG-TERM CARE}

\subsection{DEFINITION:}

Health Canada defines the current model of a long term care facility as "Care provided in facilities offering accommodation for people who require on-site delivery of supervised care, 24 hours a day, 7 days a week, including professional health services and high levels of personal care and services (e.g., in nursing homes and residential continuing care facilities). The acuity of people receiving long-term care is generally less than that of patients in acute care or complex continuing care settings." 1 Presently throughout Canada there are several different levels of support for those individuals usually

\footnotetext{
1 "Définitions." Définitions. N.p., n.d. Web. 15 Feb. 2015.
} 
over the age of 65 years old. These levels of care, known as the Pillars of Continuing Care are: Home Care/Community Support Services, Supportive/Assisted Living, and Facility -Based Long-term Care. Home Care/Community Support Services consists of services offered to clients with minor health conditions and needs at their personal residence. The client is independent and requires no supervision or security. Some outreach services could include physiotherapy, personal care, occupational health services and speech therapy. Supportive/Assisted Living gives four or more adults a home like environment which allows for independence while servicing the clients' changing needs and health requirements. This setting often has some safety and security protocols. Examples of Assisted Living facilities are senior's lodges and group homes. As previously stated, Facility-Based Long-Term care provides 24 hours a day/ 7 days a week 
service to its clients. This service is provided on-site only as full-time trained staff is required. Its clients have the least amount of independence of the four pillars of Continuing Care. Facility-Based Long Term care is regulated by individual provinces and territories. Facility-Based Long-Term care can be identified differently from province to province as nursing homes, personal care facilities, and residential continuing care facilities. Services within these facilities vary also from province to province.

\subsection{FORECAST:}

Canada is facing a growing challenge when it comes to providing quality long-term care. Baby boomers are aging and it is expected that by the year 2036, $25 \%$ of the entire population will be 
over 65. With life expectancy rates also increasing it is to be expected that progressively the need to provide habitation and care of individuals across Canada will increase significantly and rapidly. A comparison analysis of individuals from 1979 to 2012 undertaken by Statistics Canada revealed that "35 years ago, the average life expectancy at age 65 was almost 80 years old for men and 84 years old for women. In 2012, the average life expectancy at age 65 was almost 84 years old for men and almost 87 years old for women."2 Also noted in the analysis is that "currently $20 \%$ of 65 -year-old women and $17 \%$ of 65 -year-old men will live past age $95 " 3$. Existing government programs will only cover half of the forecast $\$ 1.2$ trillion in future costs of long-term care. Presently across Canada the current system is not

\footnotetext{
2 "Long-term Care in Canada. Senior Care in Canada Information and Long Term Care Planning Canada - Information for Families, Caregivers, and Seniors on Care-Years Planning." Long-term Care in Canada. Senior Care in Canada Information and Long Term Care Planning Canada - Information for Families, Caregivers, and Seniors on Care-Years Planning. N.p., n.d. Web. 19 Mar. 2015. ${ }^{3}$ Ibid
} 
publicly insured under the Canada Health Act. Governed by provincial and territorial legislation, the range of serviced and cost coverage provided differs throughout the country. This will have a spiralling effect on both the individuals requiring the care as well as those families acting as support.

Across Canada the current system is not publicly insured under the Canada Health Act. Governed by provincial and territorial legislation, the range of services and cost coverage provided differs throughout the country.

\subsection{BEST CARE - HOME CARE:}

In most Scandinavian countries there has been a shift to the Home Care model. They have come to realize that the best place to care for seniors is in their home/community. There are still the typical 
Long-Term Care facilities; however, the shift to decentralize Long-Term Care had been recognized for its benefits "The logic of decentralization is based on an intrinsically powerful idea. It is, simply stated, that smaller organizations, properly structured and steered, are inherently more agile and accountable than are larger organizations.". ${ }^{4}$

Sweden's model of care allows for seniors to stay at home and live normal, independent lives for as long as possible. Even when it is no longer possible to carry on with life independently, they can use the home-help services that based on assessment of need provides assistance around the clock. This allows for the individual to stay at home for the rest of their lives. Health and social care is provided in the home of not only the elderly but the severely sick too. The

\footnotetext{
4 "Elderly Care in Sweden." Sweden.se. N.p., n.d. Web. 31 Mar. 2015.
} 
benefits for staying in your family home and community can be easily argued. The stress of leaving family, friends and the hometown can be avoided. Despite this intriguing style of home care, it does come with some flaws. "Today about $25 \%$ of all housing is assessed as being accessible to the elderly. Nevertheless, the elderly often live in "older" homes; with narrow spaces, many steps and no elevator. The question is whether or not it is possible to adapt existing homes and areas so that the elderly can continue to live well at home. And how big a problem is the hidden misery of the people trapped in their own homes? Insecurity and isolation are significant problems, just as disabling as physical or mental illness." 5 The Swedish Delegation on Elderly Living concluded it's not possible for everyone to stay at home.

\footnotetext{
5 "News." : Integrated Service Areas. N.p., n.d. Web. 18 Feb. 2015.
} 
It is exploring other housing options that allow for the care of those individuals.

How can seniors reap the benefits of staying home and in their community without compromising their personal level of care? Is it possible to marry the two types of care, both Home-Care and LongTerm Care to best serve the elderly with the least amount of disruption to their lives?

\subsection{LONG-TERM CARE - PRINCE EDWARD ISLAND:}

The province of Prince Edward Island recently constructed four new long-term care facilities across the Island to replace several aging facilities. An architectural model was designed, developed and 


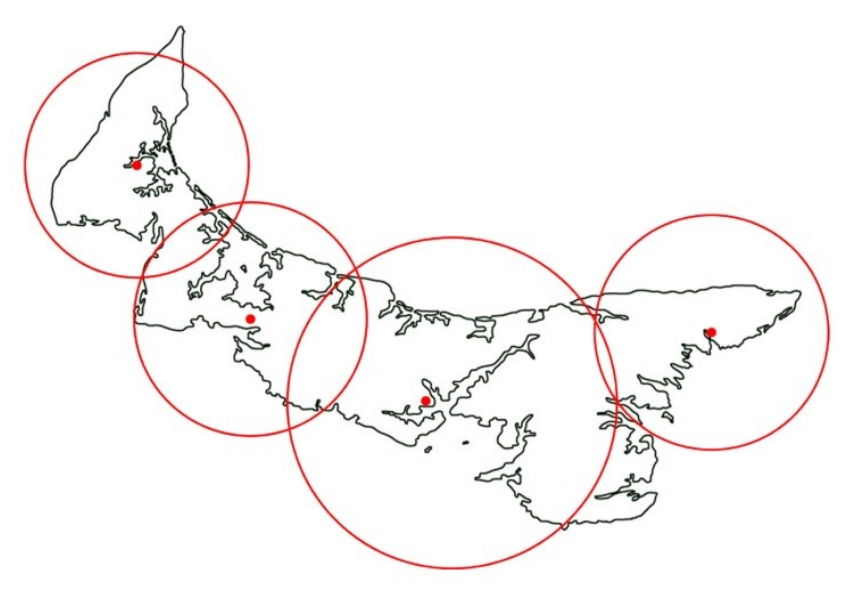

Figure 1: Mapping diagram of the four new Long-Term Care facilities across Prince Edward Island. implemented in the construction of all four. The facilities were placed strategically across the Island specific to regions of major population and economic growth. The overlapping circumference of each now encompasses the Island as a whole, requiring residents from rural communities of PEl to relocate from their local communities to one of the larger centers. Ranging in size from 48 to 120 beds, 6 the creation of the four facilities, although intended for comfort, remains institutional in both scale and aesthetics.

${ }^{6}$ "Health PEl: Long-term Care." Health PEl: Long-term Care. N.p., n.d. Web. 14 Feb. 2015. 


\subsection{PREDECENT: PRINCE EDWARD HOME}

The Prince Edward Home, the largest of the four new facilities constructed, is located in Charlottetown, Prince Edward Island. Comprised of 120 beds, the facility houses residents from a 60 kilometer radius. ${ }^{7}$ The facility was designed in partnership with Bergmark Guimond Hammarlund Jones Architects from Charlottetown, Prince Edward Island and Montgomery Sisam Architects from Toronto, Ontario. The project was completed in 2013 at a total cost of $\$ 13$ million dollars. ${ }^{8}$

"The new Prince Edward Home is designed to integrate a variety of residents including those with dementia, those in longterm care, and those seeking restorative care. PE Home was

\footnotetext{
7 "Health PEl: Prince Edward Home." Health PEl: Prince Edward Home. N.p., n.d. Web. 14 Feb. 2015.

8 "Prince Edward Home - BGHJ Architects." BGHJ Architects. N.p., n.d. Web. 14 Oct. 2014.
} 


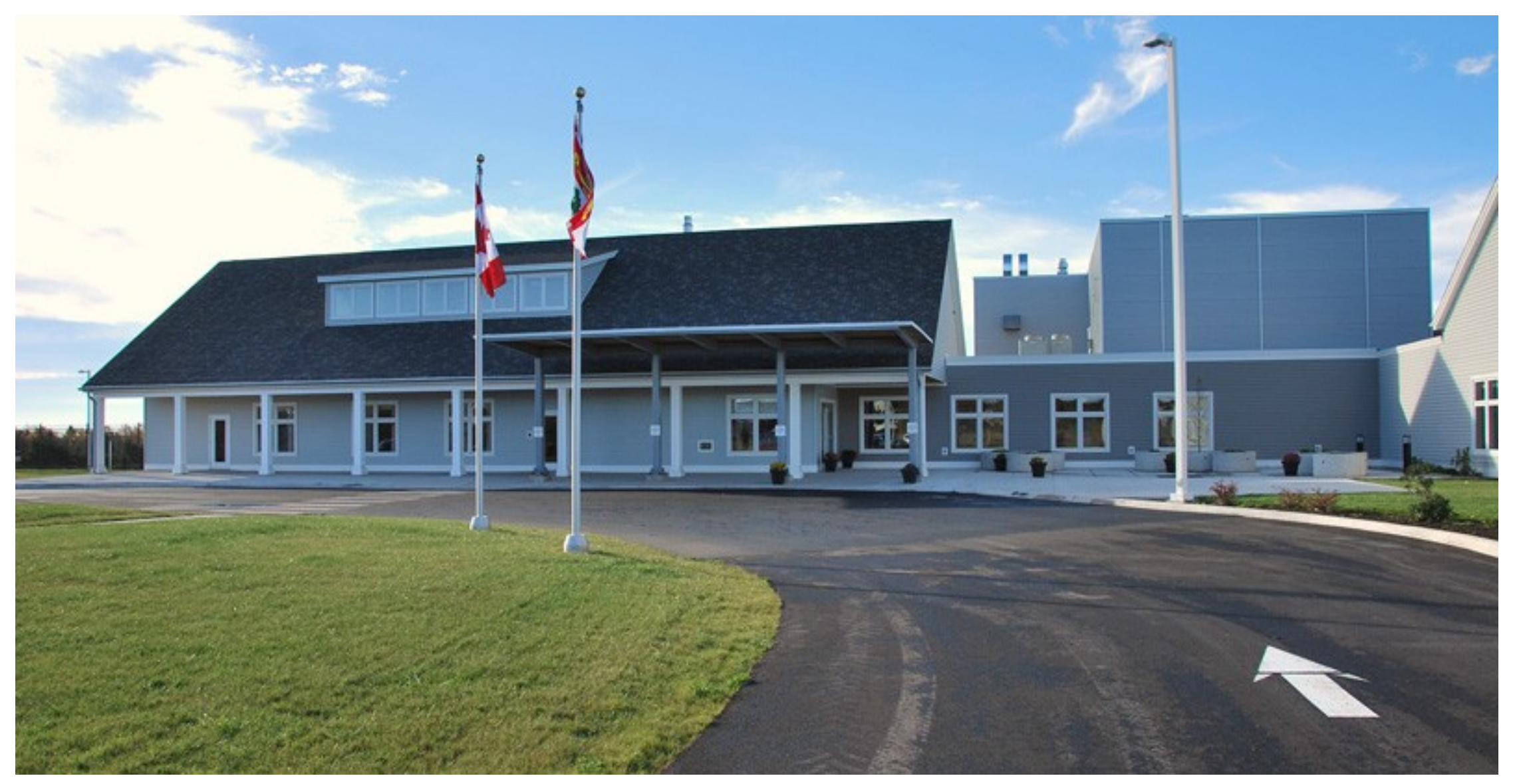

Figure 2: Prince Edward Home, Charlottetown, Prince Edward Island. Source: www.bghj.com 
designed to provide a sense of community and to maximize the comfort, dignity, and privacy of its residents." 9

Services provided to the residents at the Prince Edward Home include: medical support, pharmaceutical, recreation \& therapy, pastoral, palliative care, meals, housekeeping, social work and various volunteer services. All of the following define a living condition where the resident may reside without the need to leave the facility.

"PE Home's neighborhood/household concept formally replicates the variation and structure of an urban environment, facilitating the creation of smaller community groups that interrelate with one another. The "neighborhood" and 
"household" organization of the project provides layers of intimacy promoting resident comfort and a sense of home."10

An attempt to recreate a "neighborhood" within the urban scale of Charlottetown was chosen by the Province to save money. Too often services are being taken out of rural PEI in favour of centralizing health care. Unfortunately, the option for residents to stay within their own physical neighbourhood/ surroundings and receive the level of care that they require has been taken away from them in favour of large facilities located in urban areas. The Architects that designed the new Prince Edward home argued that they achieved the creation of a neighbourhood, household and community within the new Prince Edward Home in Charlottetown. The fault in this logic is the understanding of neighbourhood, household and community. To 
recreate a sense of neighbourhood, household and community would require a thorough examination of what neighbourhood/household/community means to the average client at the facility. In the most minimal sense of the word community is defined as a group of people living in the same place or having a particular characteristic in common. From a sociology stand point community is much more complex. One criteria that sociologists attribute to community is "an organic natural kind of social group whose members are bound together by the sense of belonging, created out of everyday contacts covering the whole range of human activities."11 The everyday routines, social interactions with locals, and the familiar scenery are not reproducible. It is often difficult for older people to leave the physical space of their home. The exit

\footnotetext{
11 "Common Menu Bar Links." Home and Community Care. N.p., 01 Oct. 2004. Web. 22 Mar. 2015.
} 
from the community they belong to and know can cause anxiety and depression.

Clients are taken in and put in one of four centralized institution. Clients can come from anywhere within a radius of $60 \mathrm{~km}$. This is significant on an Island that is roughly $250 \mathrm{Km}$ tip to tip. Within $60 \mathrm{~km}$ there are many small communities that the elderly have called home for many years. It is pretentious to think that community can be replicated in a centralized institution. These communities at their core differ from an "urban environment" by their tranquility and small town values. By centralizing Long Term Care facilities, the province is isolating its elderly from the comforts and familiarity of their community. The feeling of "home" is often equated by being surrounded by loved ones. By centralizing Long Term Care to urban areas also makes it difficult for friends and family to visit regularly due 
to the long commute and inconvenience of coming into the city. BGHJ architects oversimplifies the definition of neighbourhood, household and community by creating a 12 to 14 person "neighbourhood" -- a corridor of rooms that share a kitchen and dining hall. These clients are strangers to each other that come from different communities and backgrounds. The premise that a kitchen and dining hall is enough to foster community or a neighbourhood feeling shows a lack of understanding of the impact community and home has on an individual.

\subsection{PERSONAL INVESTIGATION:}

Personal investigation and visitation to the current model provided a journey of disconnected transition from arrival, the visit and departure. Residents differing in need and personal support are 
with little verbal and/or physical abilities are placed next to clients that are mentally alert and have fewer physical ailments. The different gradients of cognitive and physical abilities are not taken into consideration when placing clients. This can create a lonely environment within the "neighbourhood". The clinical environment provides hard sterile surfaces, double loaded tenant corridors and an extreme sense of enclosure.

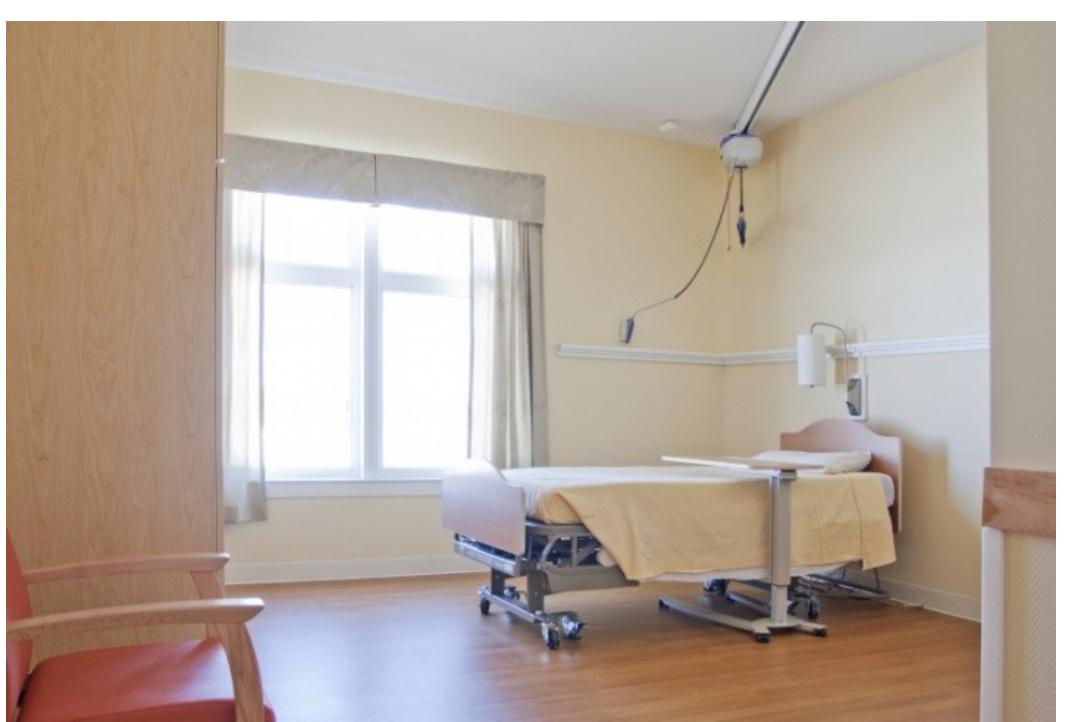

Figure 3: Typical unit. Prince Edward Home. Source: www.bghj.com

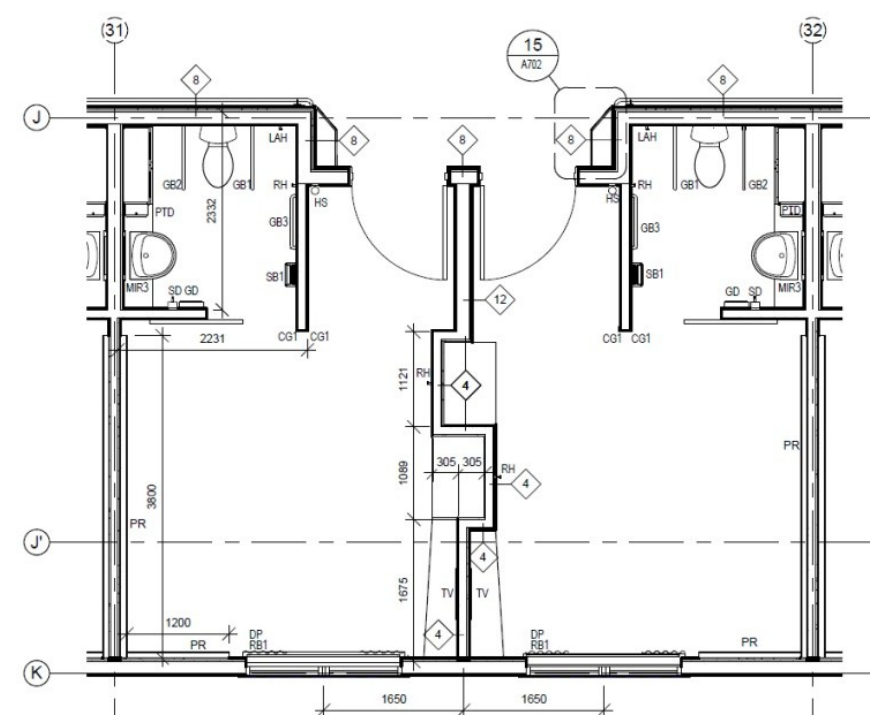

Figure 4: Unit floor plan. Prince Edward Home. 


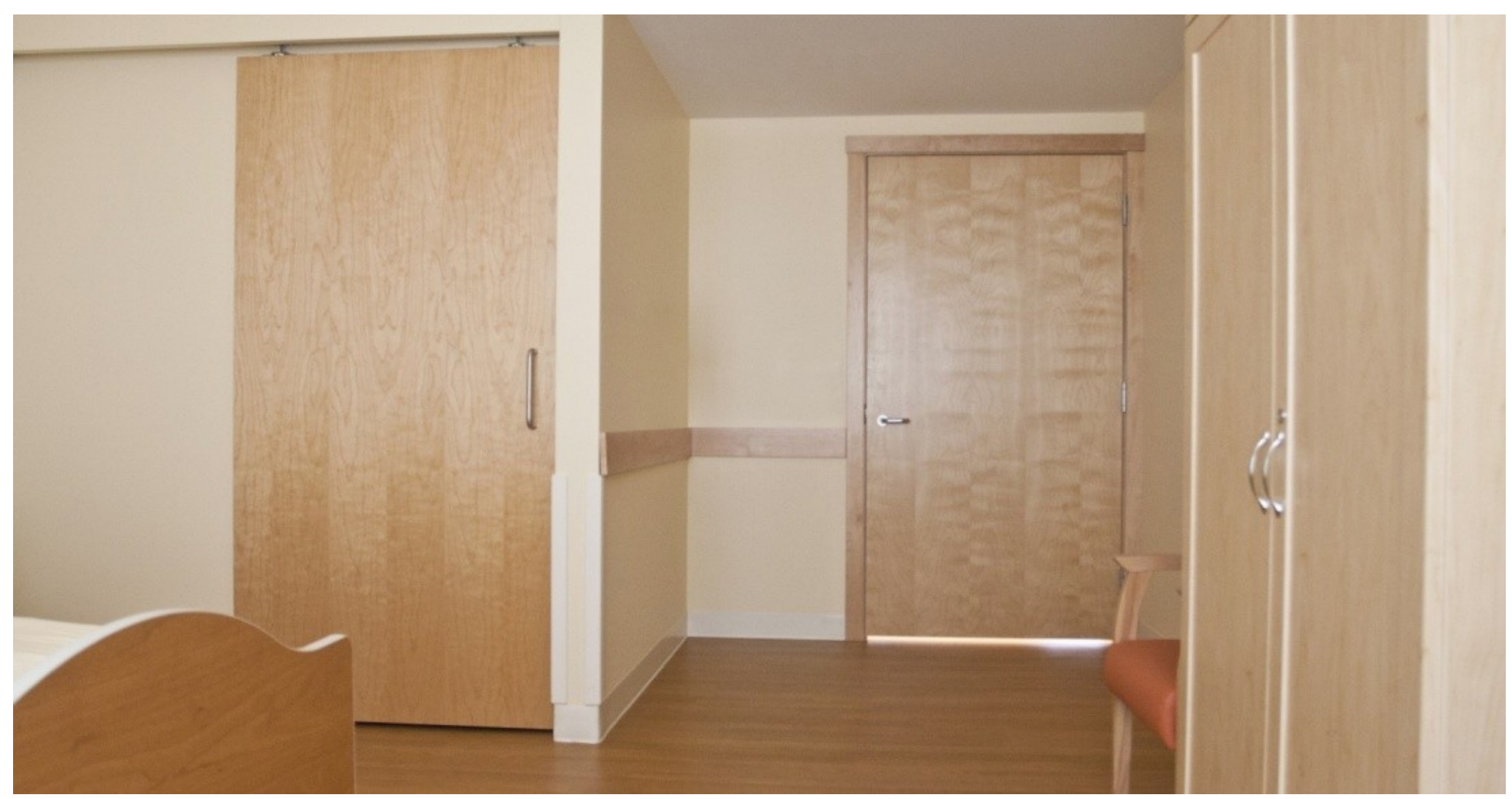

Figure 5: Interior finishes of typical unit. Prince Edward Home. Source: www.bghj.com 


\section{THE OCCUPANT}

Relocating a family member from their home to a long-term care facility requires uprooting and relocation. Moving from a home scenario to a facility based environment in most cases is a drastic change of surroundings. The three primary categories of people whom experience and are affected by the current long-term care facility include the resident, the family members or persons who may visit the residents, and the support staff that care for the residents. Each group of individuals will experience such facility in a different manner. 


\subsection{THE RESIDENT:}

The resident is defined as an individual, usually above the age of 65 years, who resides full time in the facility and requires skilled nursing care to assist in their daily routine.

Transitioning the resident from their home to a facility creates fear and anxiety. According to a 2007 study, Aging in Place in America, "older adults currently fear moving into a nursing home and losing their independence more than they fear death. When asked what they fear most, older adults' top four responses were: loss of independence (26\%), moving into a nursing home (13\%), giving up on driving (11\%), and loss of family and friends (11\%). Only $3 \%$ of seniors 
said that death is what they fear most." 12 This problem can in a large part be attributed to the "form and location of nursing homes and other senior housing facilities. For the past fifty years, senior housing developments have been predominantly approached as specialized suburban forms that are usually organized around recreation facilities, medical supports, or both. The developments have been agesegregated, often regulating the amount of non-senior residents and the duration of stays of non-senior visitors."13

The resident's physical health most often deteriorates and the quality of life will lessen due to the environment and its surroundings. There is a lack of consideration for the level of need and care for individuals creating a condition where persons of varying functional

\footnotetext{
12 "Evolution in Senior Housing." American Architectural Foundation. N.p., 18 Feb. 2013. Web. 19 Apr. 2015.

${ }^{13}$ Ibid
} 
abilities may be grouped together. Mixing residents of differing needs and alertness may reflect in the decline of one's health from the time they arrive. Some of these changes might affect a resident's well being and rapidly change and affect their general health. In life, we tend to be encouraged and supported on an everyday basis by those who surround us in both mind and spirit.

The prototype developed in this thesis investigates the current living environment and proposes a healthier and more stimulating way of living. Consideration of the resident's current state of health upon arrival will determine their unit placement in the facility. Individuals will be placed with consideration to the level of care they require. More independent residents will be aligned in neighbouring units to encourage communication. Providing an internal corridor for circulation that resembles that of an exterior living condition will allow 
the resident units to feel disconnected from the main services of the building with the intention of each unit appearing separate and creating a sense of ownership for each resident.

\subsection{THE VISITOR:}

A visitor is an individual that has a connection to the resident. Visitors may act as support and come to spend time with the resident. Visiting a loved one in the current provincial long-term care environment resembles the experience of visiting a major health care facility. Sterile, artificially lit corridors, lined with solid metal doors provide the journey when accessing the resident's unit. With security becoming of utmost importance, the units become groups within 
secure zones, disconnected and creating a sense of translucency to an exterior environment.

While of course the primary focus is on the residents, the mental state and well being of the visitor can also be affected when visiting a loved one. Both on arrival and departure of the facility, one might have feelings of guilt for placing the person or family member into such an environment. The contrast of the resident's former rural environment with their new urban surroundings is overwhelming and hard to process for both the visitor and the resident.

Providing a space within the resident's unit for the visitor to stay for extended periods of time, share meals, and simply feel at home are key elements to continual support of the resident. A specific entrance for the visitor into and out of the main building as well as 
exterior entrances to each resident's unit will provide an ease of access. Having a more direct access to the resident and eliminating the need to funnel though one specific region of the building to access the resident's unit will create a sense of freedom for the visitor to come and go at their leisure. A more direct access will create independence for the visitor while eliminating the exposure to neighbouring units and individuals of differing cognitive behaviors.

\subsection{THE SUPPORT STAFF:}

The support staff of a long-term care facility encompasses a range of health care providers in the form of on-call doctors, registered nurses, administrative staff, food service employees, and janitorial persons. Present working conditions, place these individuals 
behind the scenes creating a working condition with offices and exam rooms programmed internally, creating a work environment that is lacking in natural day lighting and disconnected from the outside world. Support staff carries the responsibility of care and well being of the resident. Attitudes are often transferred to both resident and visitor.

While working at rural facilities, health care providers will have the opportunity to stay and work within their rural communities. Sharing a sense of place and pride with the resident will create familiarity and a stronger connection between the support staff, the resident and the visitor.

Realignment of the existing programme will relocate the nurses' station and administrative offices to the building perimeter in order to 
allow natural light and exposure to the exterior climate conditions. Providing an abundance of natural light and beautiful views will provide support staff a sense of importance and value improving their current working conditions. 

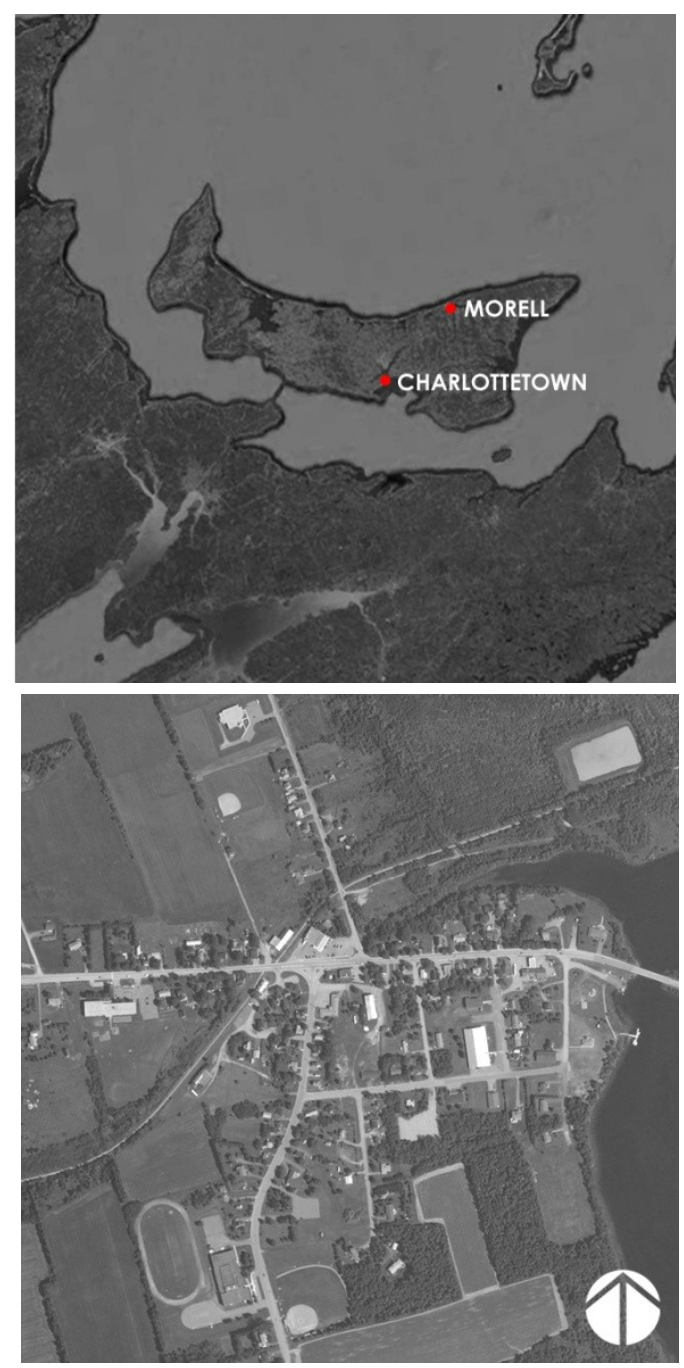

Figure 6: Macro + Micro site images. The province of Prince Edward Island + Village of Morell.

\section{THE PROPOSAL}

The site chosen for this thesis is my home town, Morell, Prince Edward Island. Morell is a small village on the northeast coastal region of Prince Edward Island with a population of 315 persons. Farming, fishing, and forestry make up the major industries of the village which is located 43 kilometers east of the provincial capital of denominations, both elementary and high schools, a local grocery store, banks, a provincial library, a community health center which houses a dental practice and a pharmacy, seasonal community center, and waterfront park. 


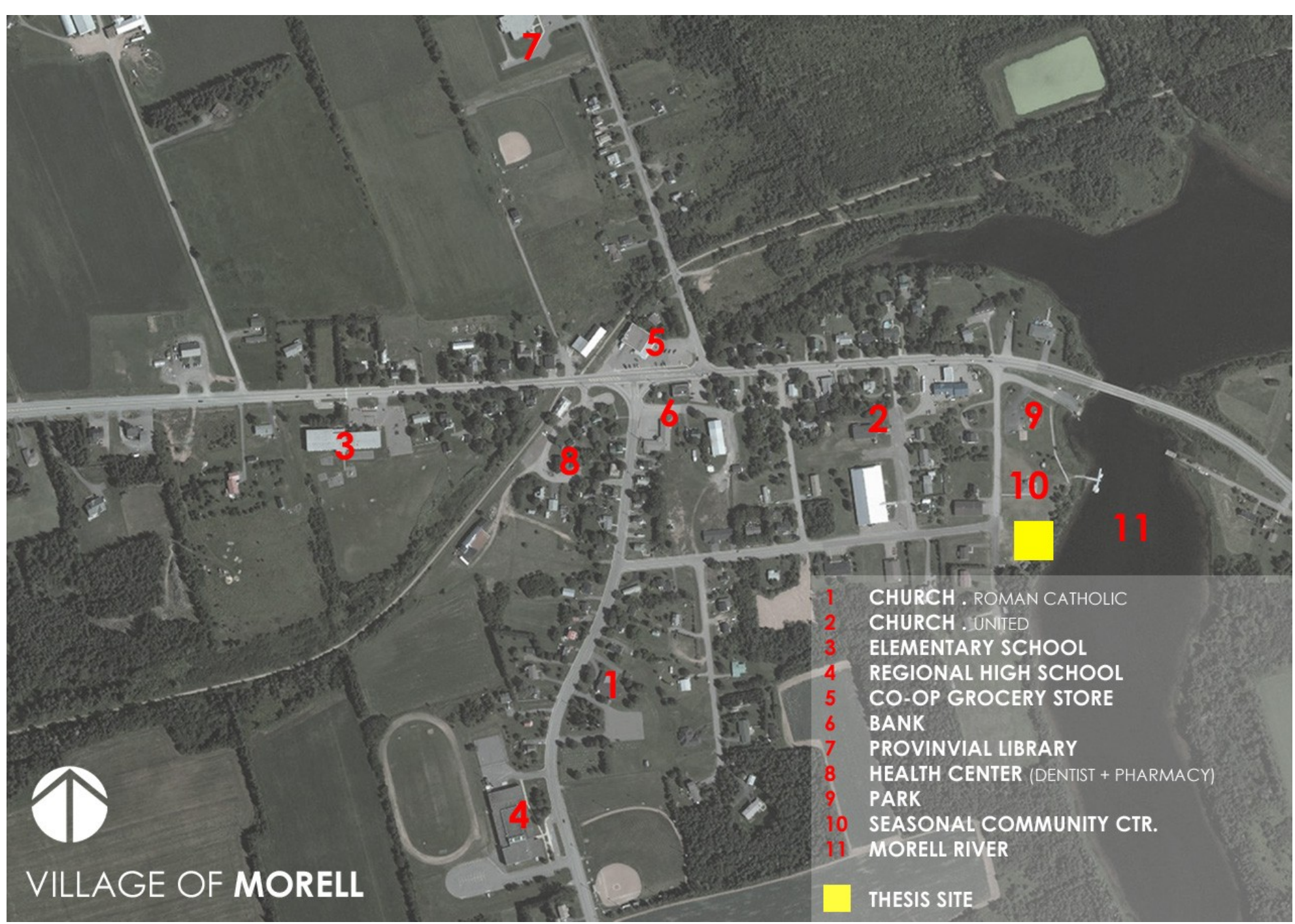

Figure 7: Micro Site Analysis: Village of Morell. Identification of infrastructure. 
The past decade has seen a major decline and lack of services for the village with the removal the medical practice, the closure of several restaurants, and the decline of populations as younger families are leaving the community. The driving force behind the decline of the village or Morell and many other communities similar in population is the provincial government. Infrastructure funding is presently allocated to larger urban regions, in particular the cities of Charlottetown and Summerside. This not only encourages but often requires people to relocate from rural areas to the larger city centers for work.

"Buildings and towns enable us to structure, understand and remember the shapeless flow of reality and, ultimately, to recognise and remember who we are. Architecture enables us to perceive and understand the dialectics of permanence and change, to settle 
ourselves into the world, and to place ourselves in the continuum of culture and time." 14

Being raised in a small rural community on Prince Edward Island, I have been witness and affected by the recent decline in community presence, population and lack of infrastructure. These factors combined provide reason for selecting the village of Morell as the primary site for my design proposal. Like myself, "people often develop emotional bonds to places that are sites to positive experiences and memories. Individuals may develop their strongest attachment to places they find particularly attractive, that they chose

14 Pallasmaa, Juhani. "The Task of Architecture." The Eyes of the Skin: Architecture and the Senses. Chichester: Wiley-Academy, 2005. 71-72. Print 
to frequent, or that support positive social interactions and the development of social ties."15

15 Dannenberg, Andrew L., Howard Frumkin, and Richard Jackson. Making Healthy Places: Designing and Building for Health, Well-being, and Sustainability. Washington, D.C.: Island, 2011. Print. 
"Morell was the first commercial capital and center for activity. Building of 100 tonne ships to transport fish to Europe and the West Indies was carried on here. The community was now booming and housed twelve scallop boats, three schooners, two merchants, two masters, a black smith, and a medical doctor. The population reached one hundred and sixteen, but tragically in 1738; a disastrous fire destroyed all settlements on the north shore including the tiny village. All fishing fleets were destroyed and thirteen pioneer settlers lost their lives in an attempt to save their homes. However, even after this tragic event, more settlers came and rebuilt the village."16

\footnotetext{
16 "History of Morell." Www.morellpei.com/history. N.p., 12 Aug. 2003. Web. 18 Oct. 2014.
} 


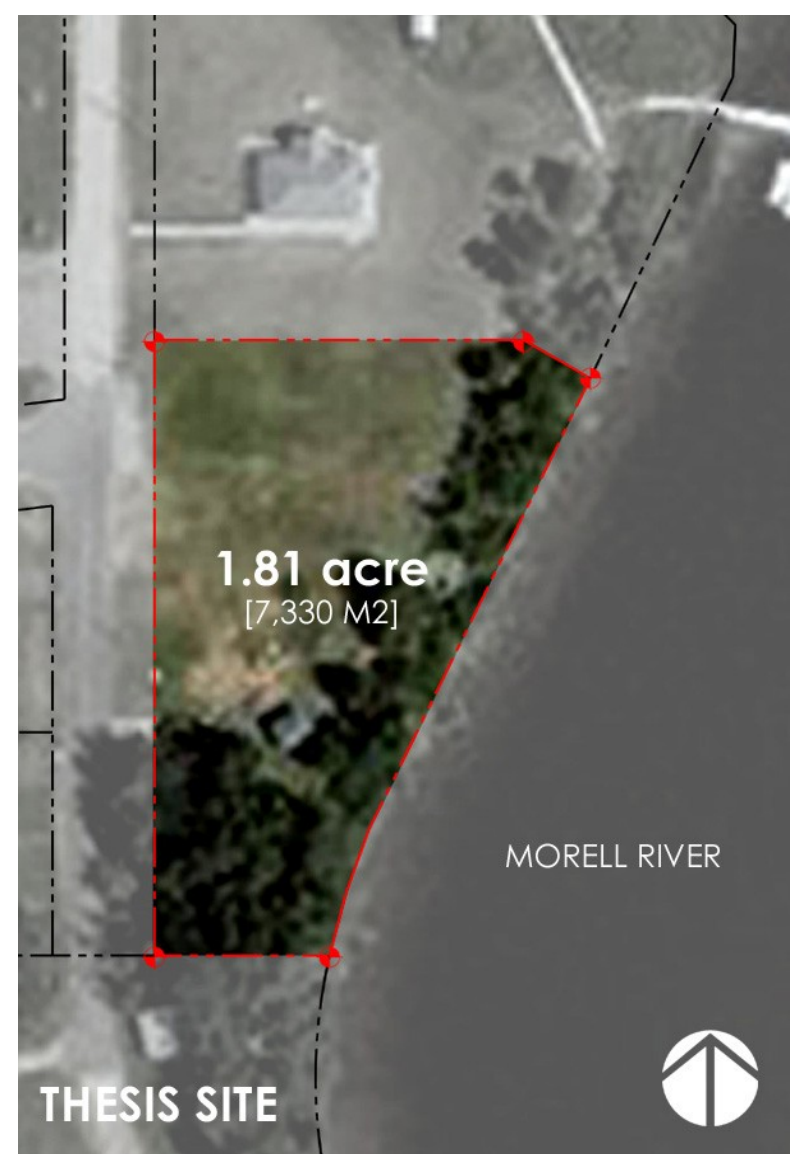

Figure 8: Thesis Site Plan. NTS.
The geographical region of the community selected as site for this thesis investigation is a parcel of vacant land adjacent the Morell river. The area of the site is 1.81 acre [7,330 M2] allowing for a buildable envelope scalable to the size of the community and resident need.

Year round access to the site is granted via Riverside Drive, a low traffic side street perpendicular to Route 2 on the east end of the village. The site is bordered on two sides with smaller scale single family residences and is adjacent to a seasonal recreation community center on the third side. Running parallel to the Morell River allows program direct water access. Existing, mature greenery borders approximately fifty percent of the water side region providing specific vistas of water and evergreens. Travelling west from the 
eastern end of the Island along Route 2, the chosen site is visible and becomes part of the gateway to the village. 

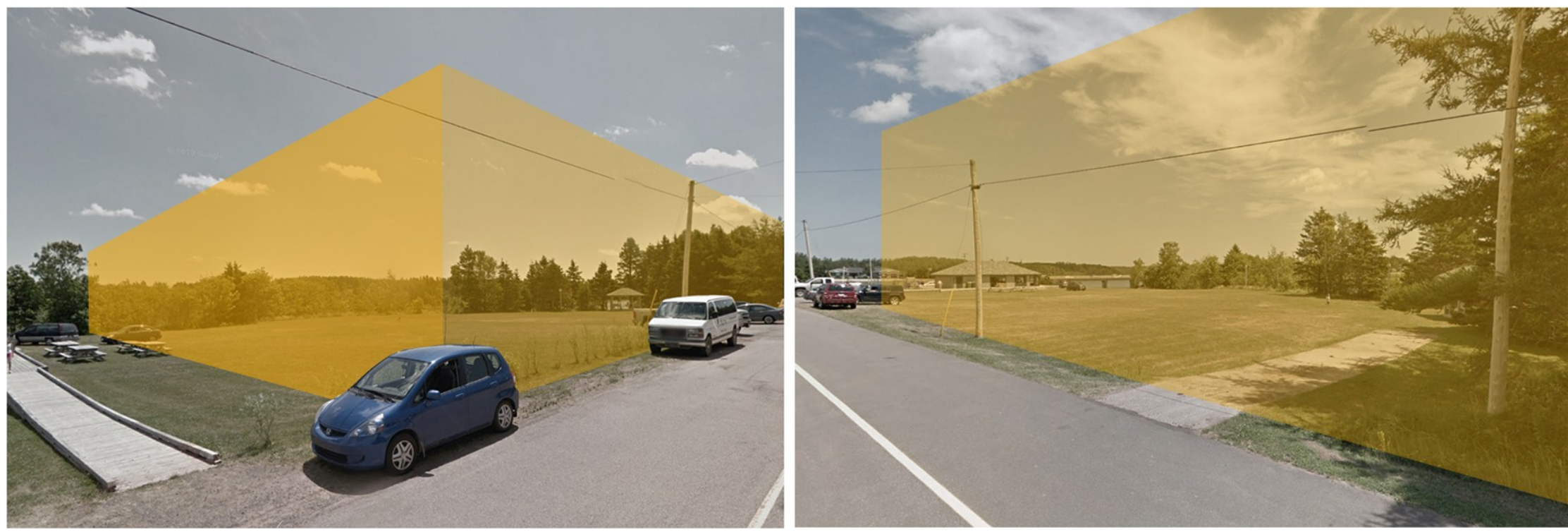

Figure 9: Street view of proposed site. Riverside Side Drive, North \& South.

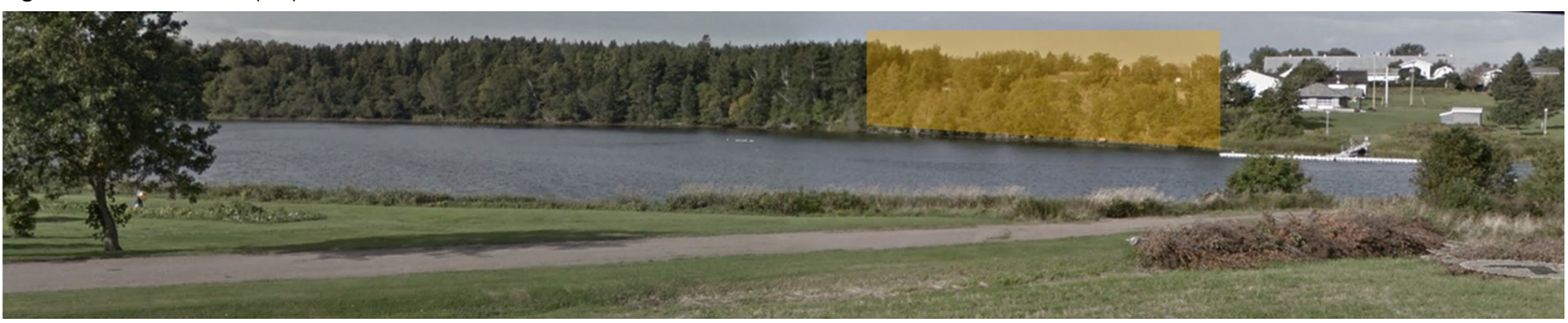

Figure 10: Street view of proposed site. Route 2, East. 


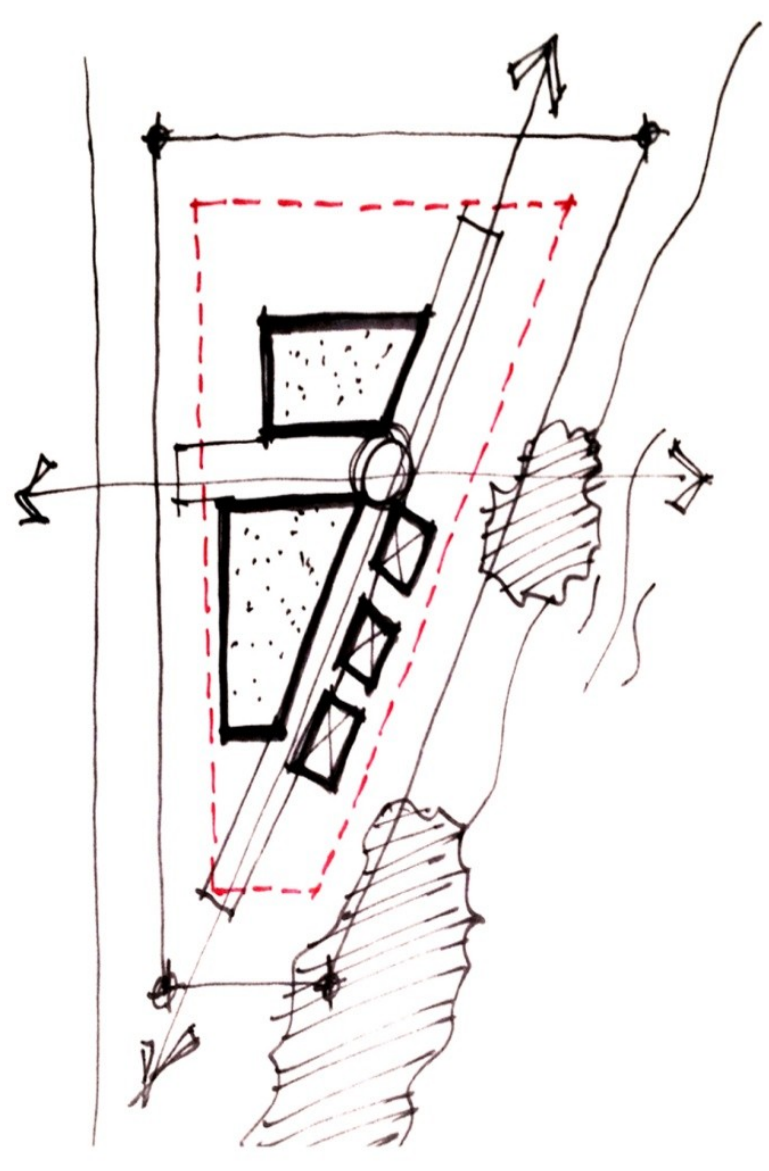

Figure 12: Site concept sketch. Buildable Setbacks

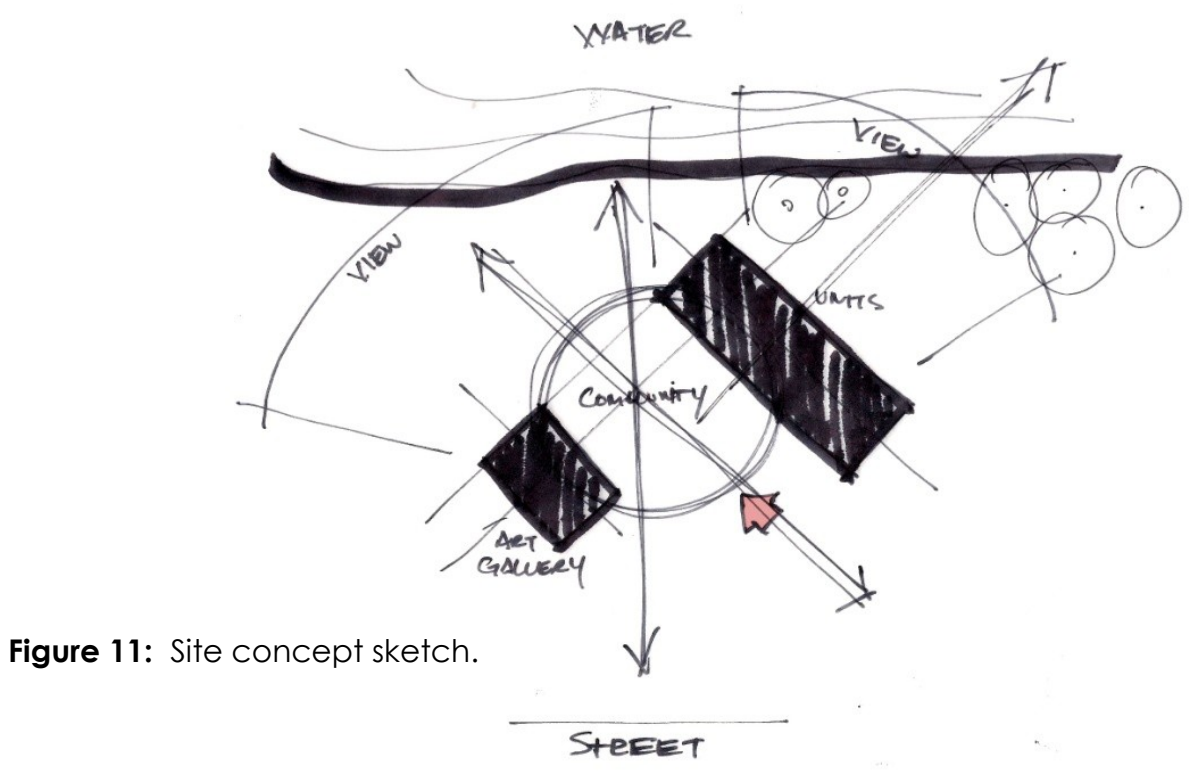

\subsection{CONCEPT DESIGN:}

Working within the buildable setbacks of the chosen site, the architectural program becomes situated between the bounties of both street and water. Consideration of public exposure breaks the conceptual design into public and private zones allowing the division to act as public access to the water. Access to the Morell River for 
public use encourages pedestrians through the building creating a unique division of public program versus private program. Locating the resident's units to the south/east side of the property will allow for morning sunlight, views of both water and greenery with the associated "seasonal changes and the possibilities they evoke always seem fresh to us." 17

Introducing an independently funded program element in the form of an art gallery/community space will provide an economic foundation to assist in sustaining the building future.

17 Knowles, Ralph L. Ritual House: Drawing on Nature's Rhythms for Architecture and Urban Design. Washington, DC: Island, 2006. Print. 

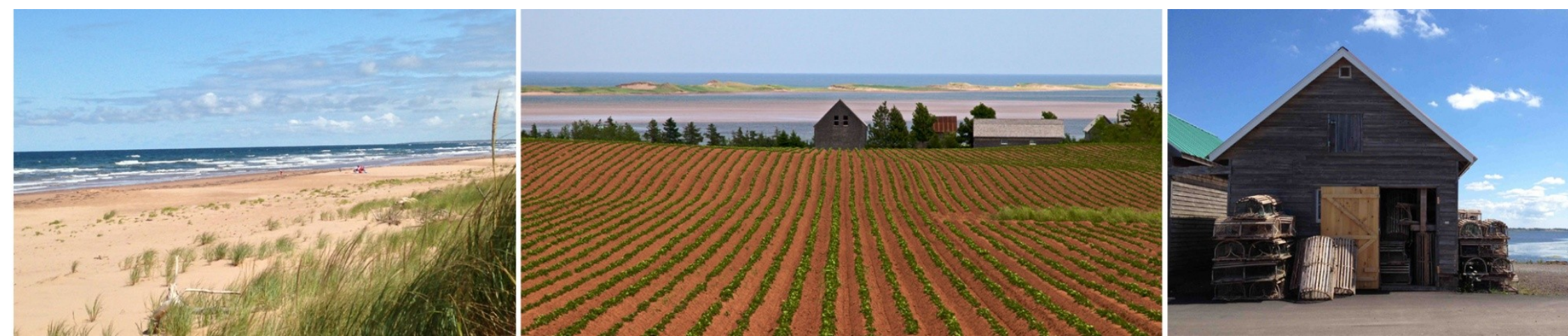

Figure 13: Regional context of Morell, Prince Edward Island.

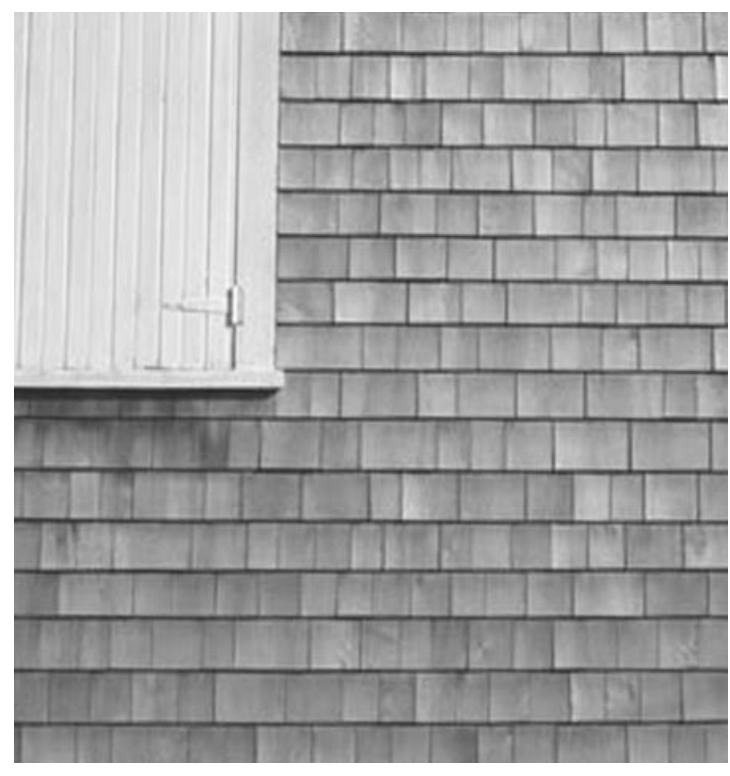

Figure 14: Windswept exterior cladding.

\subsection{DESIGN PRECEDENT:}

Local regional vernacular is developed by the surrounding homes, barns, and local Red Head lobster fishing port. Windswept cedar siding and roofs "exist in the continuum of time; the patina of wear adds the enriching experience of time to the materials" 18 and are

18 Pallasmaa, Juhani. "Materiality and Time." The Eyes of the Skin: Architecture and the Senses. Chichester: Wiley-Academy, 2005. Print. 
proof of the harsh climate of powerful winds and salt air from the Island's north shore. The use of natural wood materials, form/building mass, and the flat Island terrain allow for an architecture that is well grounded and suitable to the local climatic environment. "The flatness of today's standard construction is strengthened by a weakened sense of materiality. Natural materials - stone, brick and wood - allow our vision to penetrate their surfaces and enable us to become convinced of the veracity of matter. Natural materials express their age and history, as well as the story of their origins and their history of human use."19

Close proximity to the thesis site is the local fishing port of Red Head harbour. The horizontal wharf and multitude of fishing shacks 
are characteristic of not only the Red Head harbour but many of the other fishing harbours across Prince Edward Island. The shacks are used as storage for individual fishing fleets resembling [home] when returning from out at sea. The individual buildings, similar in scale, although independent, create a sense of unity as one anchored to the wharf. The wharf creates foundation and stability for the shacks as the sea rises and falls with the fluctuation of the tides. 


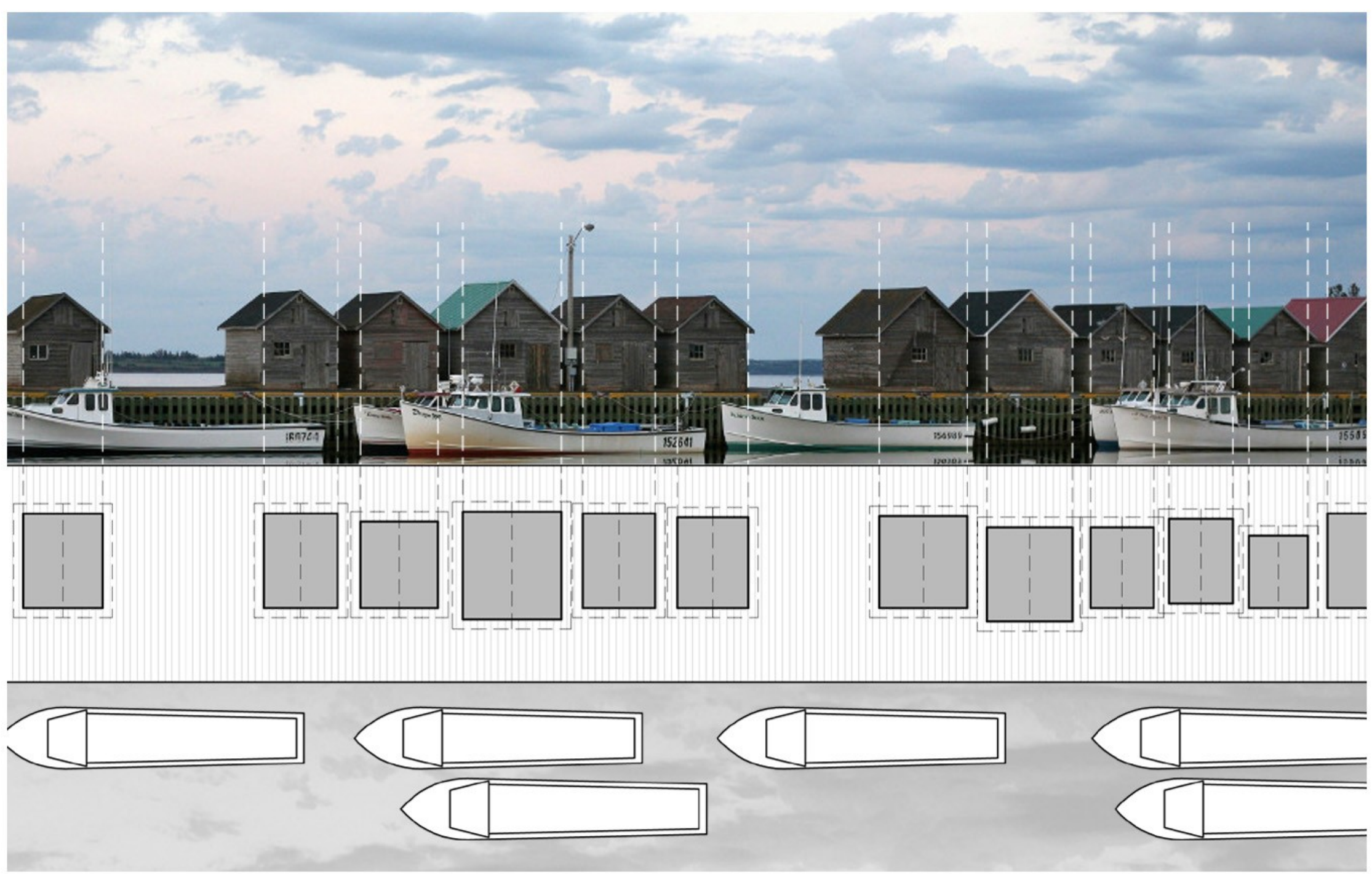

Figure 15: Red Head Harbour. Existing building elevation and plan 


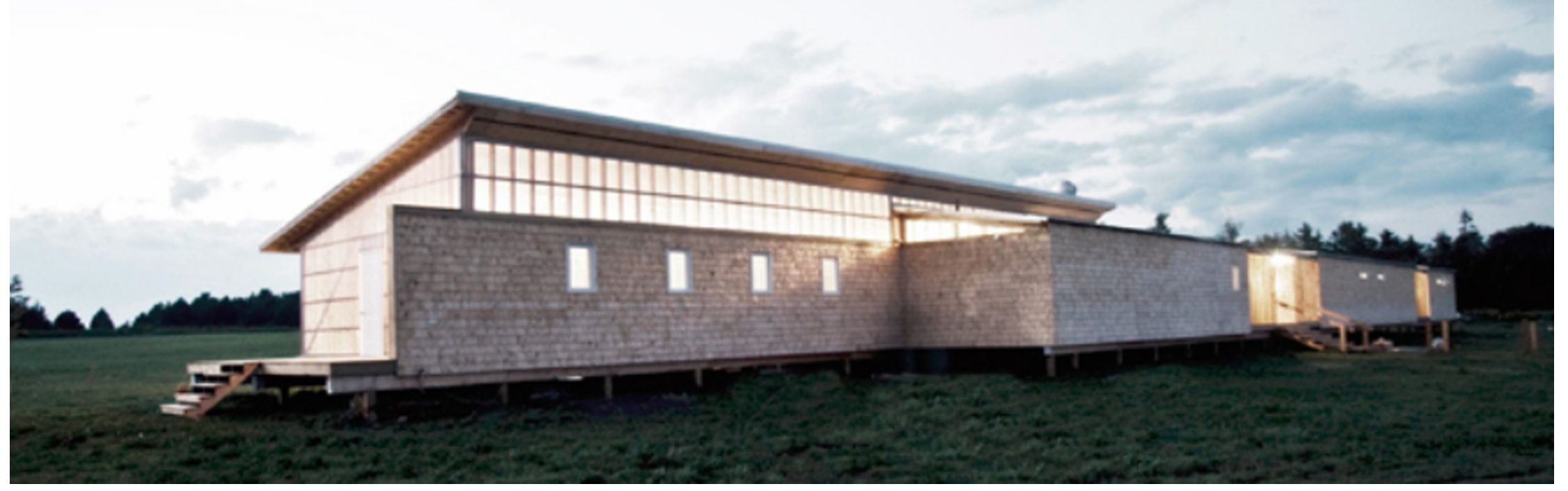

Figure 16: Cabot Beach Camp Facility. Malpeque, Prince Edward Island. Source: www.studionorth.ca

The recently constructed Cabot Beach Camp facility designed by Studio North Architecture allows for a more modern interruption of materiality and form along Prince Edward Island's north shore. Studio North describes the design as "the simple form of the building focusing on natural day lighting and passive ventilation. The heavier 


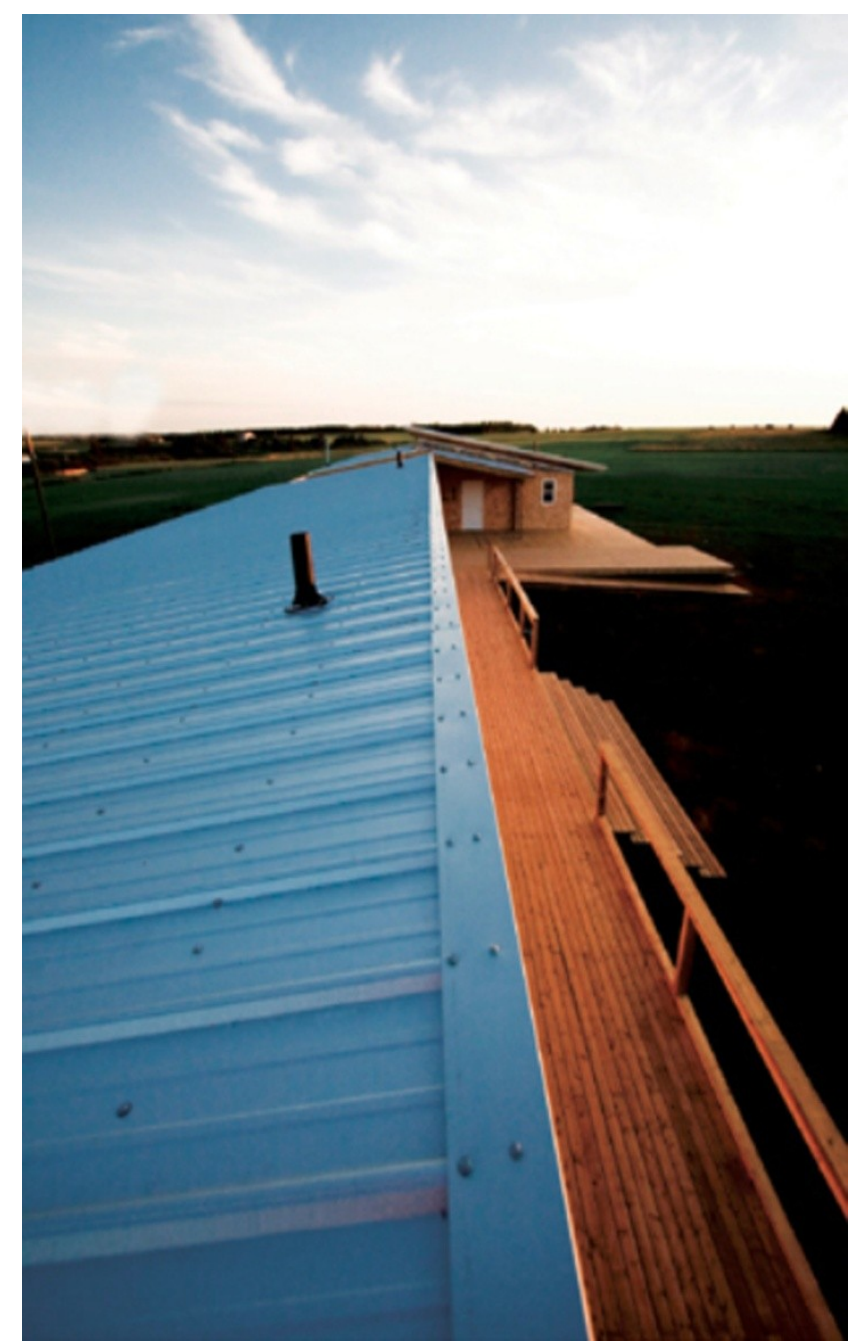

Figure 17: Cabot Beach Camp Facility. Malpeque, Prince Edward Island. Source: www.studionorth.ca southern wall is insulated to block out the hot summer sun and the noise of the active rural community, creating a comfortable retreat. The concept is to create a linear, axial plan that acts as a boundary line, defining the realm of the camp with the edge of the forest across the playing field." The design clearly denotes division of program for both public and private use. Placement of spaces adjacent one another along a linear axis allows for a journey while maximizing water views. A large deck, much like the traditional wharf, links program together allowing for areas of interior and exterior. Although the form of the building is a more modern interpretation, the materials used are in character with the location and surroundings. The use of clearstory glazing provides maximum natural lighting to the interior while maintaining privacy with solid wall surfaces. 

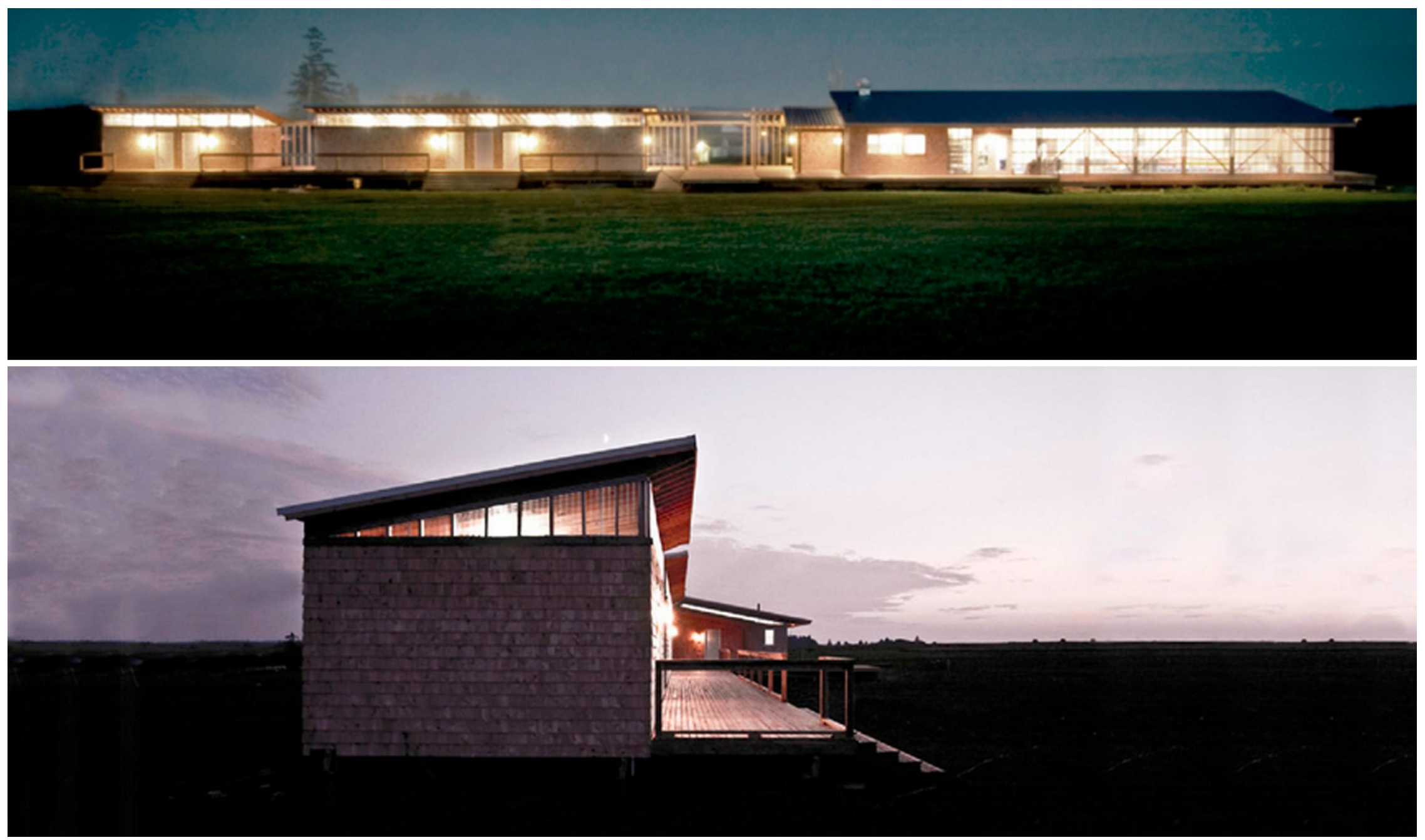

Figure 18: Cabot Beach Camp Facility. Malpeque, Prince Edward Island. Source: www.studionorth.ca 


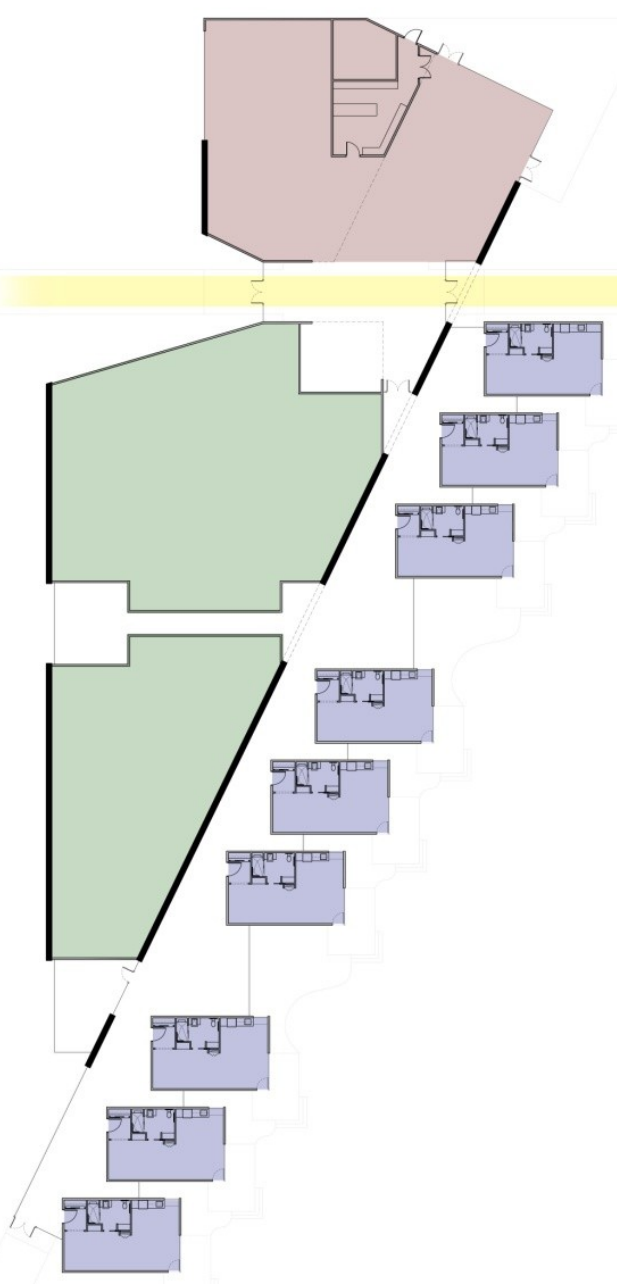

Figure 19: Four elements of building program.

\subsection{PROPOSED FACILITY:}

The decline of rural Prince Edward Island is the result of the Province restructuring its urban regions through allocation of funding and resources solely to the larger city centers. This design study proposes a prototypical Long-term Care facility specific to rural communities of Prince Edward Island. Providing smaller regional facilities with allow residents the well deserved opportunity to remain in their community or a surrounding community in close proximity. An example of this would be placing a facility in a community such as Morell with a population of 315 and catering to much smaller neighbouring communities with populations of approximately 50 . This will eliminate the need to completely relocate to one of the Provincial major facilities and remain connected to family, friends, and the surrounding services that are part of daily routine. 
The proposed program is composed of four major elements including resident care units, a public gallery/community space, pubic circulation for water access and areas of building services required to efficiently run the facility.

Providing the public gallery/community space will benefit both the resident and it will facilitate the current need for a community space in the village of Morell. Welcoming the residents residing in the facility to partake in the community social events hosted at the gallery will encourage the residents out of their individual units to socialize. Encouraging the public into the building to attend social events will also allow the public to remain connected to their elders. Reminiscence of past events and experiences had by the local residents while living in the community will act as a valuable ongoing history resource for the village. Developing a defined public access 
through the building to access the water front will also encourage pedestrian traffic though the space.

While investigating how it is feasible to support an independent facility it was apparent that other forms of revenues would be required to ensure financial sustainability. The addition of public program to neighbour the proposed facility is a way to achieve such a goal. In order to determine what external program should be added to the facility required investigation into what is needed in the community. The absence of a year round community space in the village of Morell requires events such as the annual Sportsman Dinner fundraiser, wedding celebrations, benefit concerts etc. to be held in the local high school gymnasium. Also lacking from the community is a venue for local artisans to display their work. Local artisans are 
currently required to travel to other communities to display their creations. 


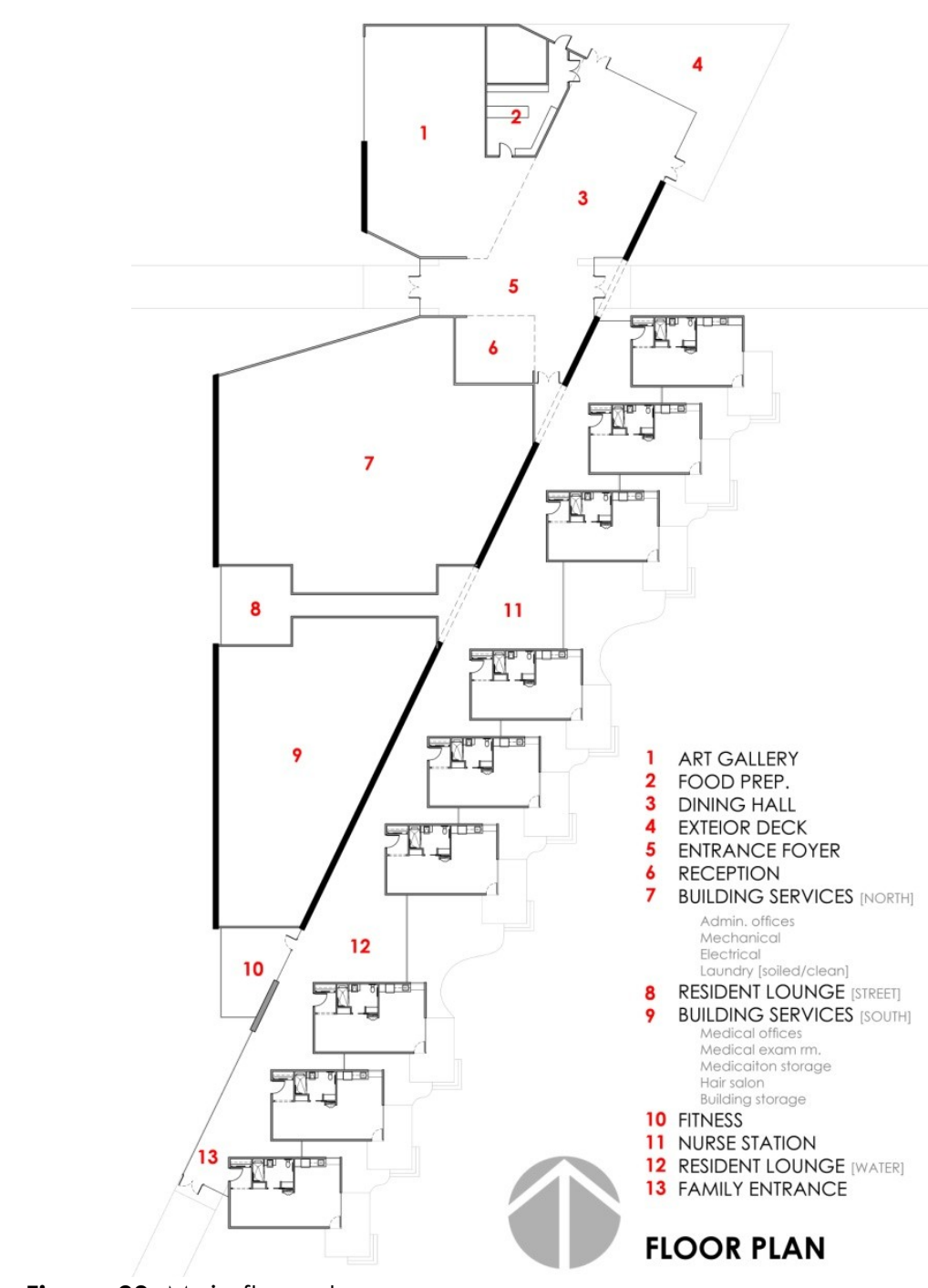

Figure 20: Main floor plan 


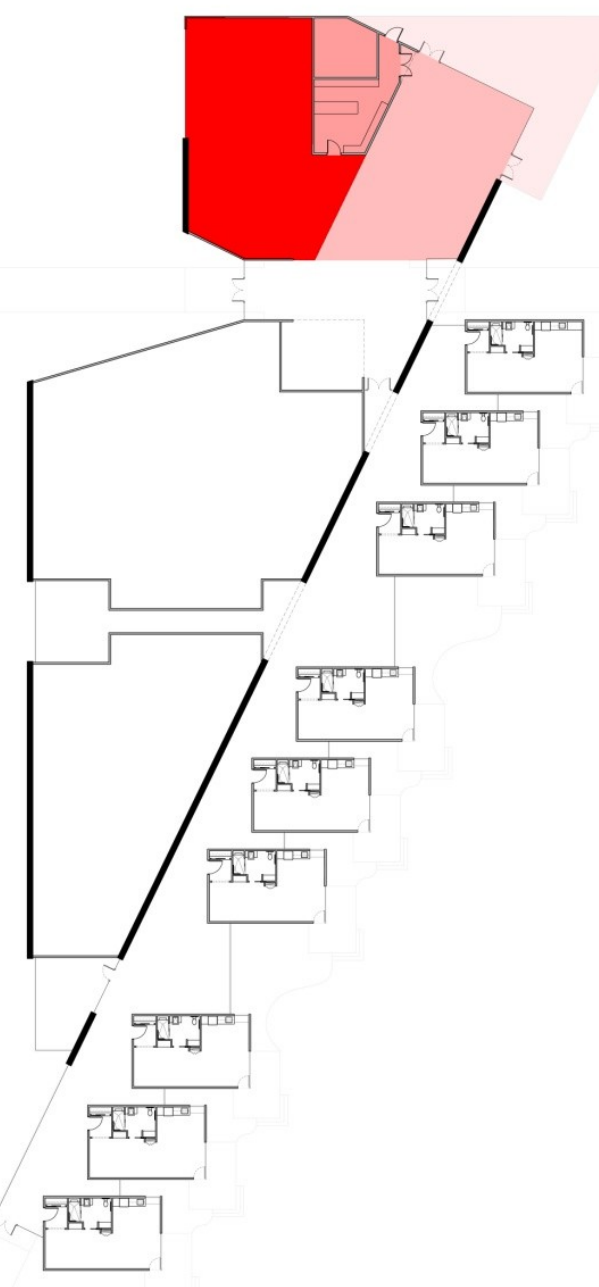

Figure 21: Key Plan: Art Gallery, Food Prep., Dining Area, Exterior Dining.

\section{Art Gallery/Community Space:}

Solid and void wall surface by way of glazing and solid building envelope are key elements integrated into the design of the art gallery/community space. High ceilings allow for panoramic views that create a sense of openness and extension to the water edge. A food preparation space centrally located caters to both the residents' daily needs as well as to social events held at the space. It is important to "promote social interaction within buildings or within neighbourhoods by providing gathering spaces on neutral territory, visual prospects." 20 Connected to a large exterior space, the interior

20 Dannenberg, Andrew L., Howard Frumkin, and Richard Jackson. Making Healthy Places: Designing and Building for Health, Well-being, and Sustainability. Washington, D.C.: Island, 2011. Print. 
has flexibility to expand to the exterior during gatherings when the weather permits. 


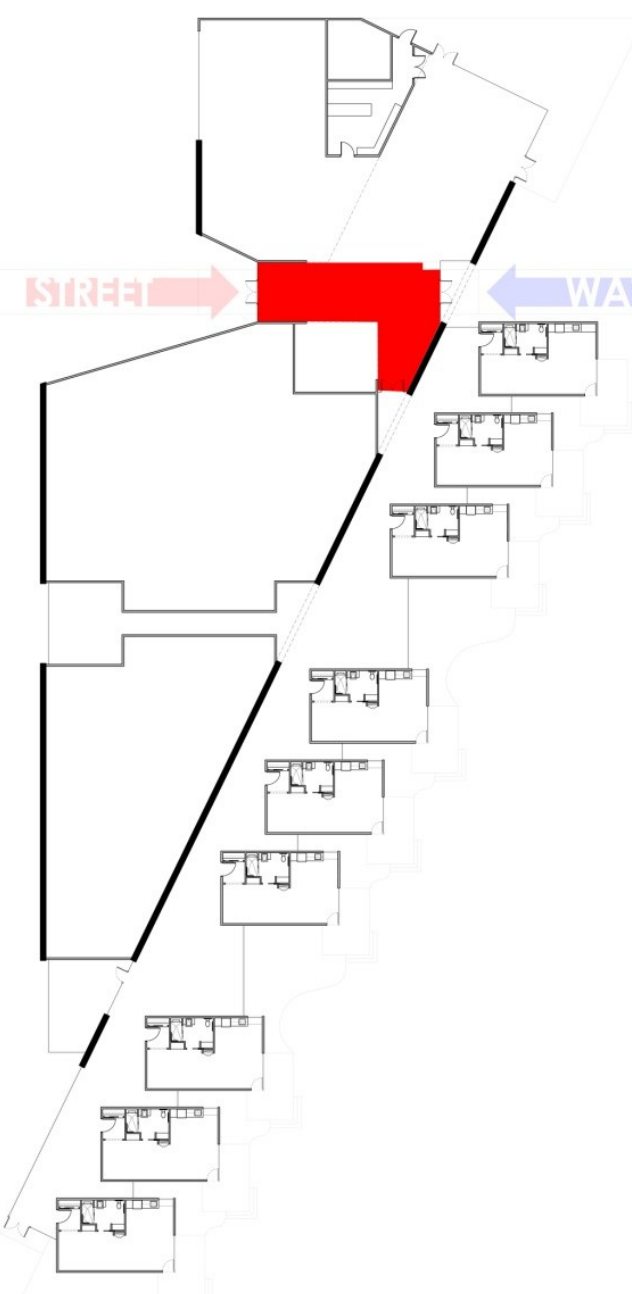

West [MAIN] Entrance:

Public entrance to the facility offers an atmosphere of openness and disconnect been the art gallery/community spaces and the resident units and building services. A wide boardwalk first greets pedestrians at the parking on the street side of the building and continues through the building out to the water. The boardwalk consists of a wood material which continues from exterior to interior and then back to the exterior with spaces simply defined by seamless glazing. The main entrance/ foyer is scaled to allow traffic to navigate east to west and north to south to link the two main program elements under one roof. Upon arrival, individuals have the availability to navigate straight through the building towards the water, turn left to

Figure 22: Key Plan: West [MAIN] Entrance. Access from street + Water. 
access the art gallery/community space, or turn right to access the reception and waiting area for the resident units. 


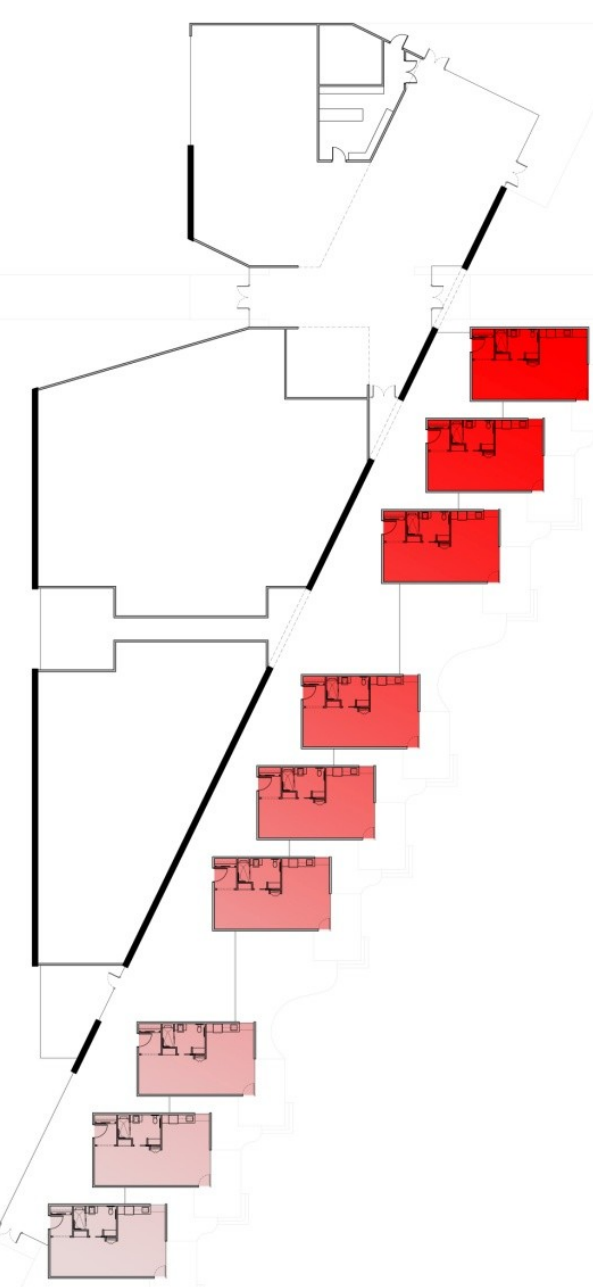

Figure 23: Key Plan: Resident Units. Illustrating (gradient in level of care).

\section{Resident Units:}

Allowing for a gradient in the level of care is a key element in creating definition towards the design of the resident units. To achieve independence for the residents, the units are disconnected from one another. Linked only by seamless glazing in building elevation, the units will appear to be self standing. Carrying the exterior materials into the building will create another level of definition towards the intent of having the units be independent. The interior circulation corridor also maintains aspects of exterior materiality, blurring the definition of what is interior and what is exterior. Glazing at either end of the unit linking corridor allows the user's eye to continue to the exterior eliminating the dead end corridor situation which is consistent with the current model considerable amount of evidence suggests 
that "exposure to greenspace promotes healthy psychological development."21

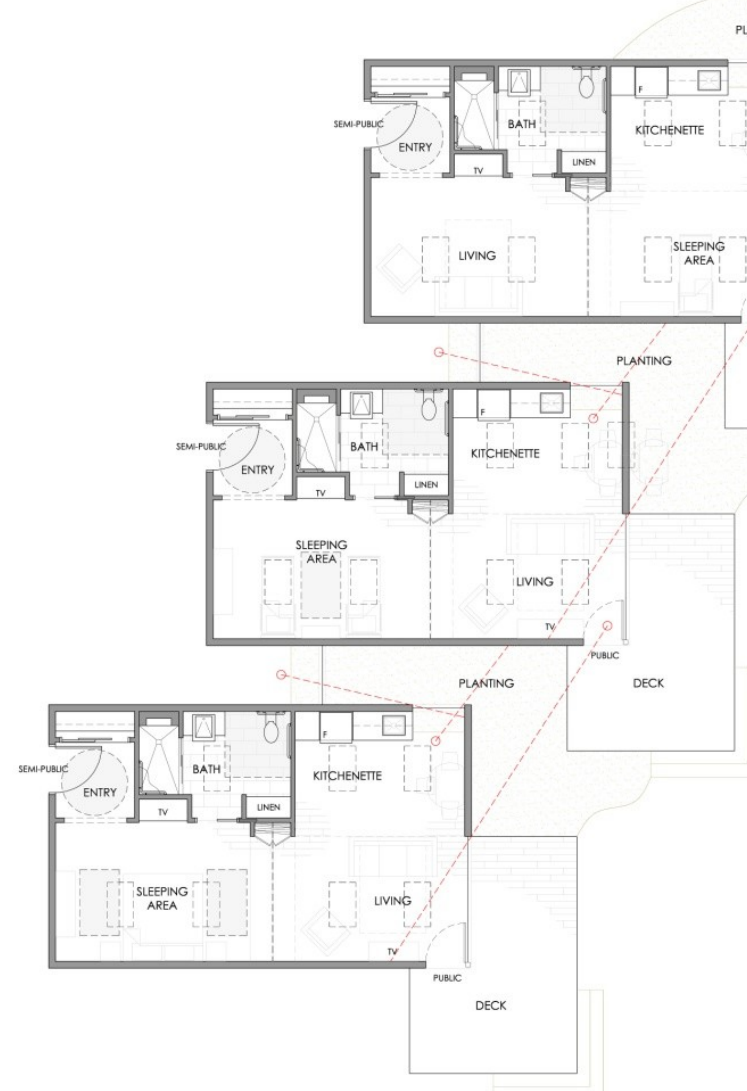

Figure 24: Resident Unit Layout.
21 Dannenberg, Andrew L., Howard Frumkin, and Richard Jackson. Making Healthy Places: Designing and Building for Health, Well-being, and Sustainability. Washington, D.C.: Island, 2011. Print. 
also comes equipped with a sofa bed to allow for family of the resident to stay for a night or two. A retractable partition wall can be opened and closed to create privacy when needed between the residents sleeping area and the living/kitchenette spaces. Two entrances to the unit allow for entrance and egress. The internal entrance is designed to allow for the health care and support staff to enter the space with immediate proximity to the sleeping area in the case of emergency. The second access is a public access from the exterior by way of small exterior deck space. The public entrance is intended welcome family directly into the space with the intent of frequent visits. The exterior deck space encourages residents to proceed outside when the weather permits to enjoy the sights, sounds, and fresh air. The exterior deck space will also allow "visibility 
from a building's exterior have been linked to higher levels of perceived social support and lower levels of psychological distress." 22

Roof penetrations have been added in the form of skylights to allow natural light into the space where possible. For centuries "hospitals were built with large windows and even skylights. Although this was done for the sake of visibility, in the days before powerful electric-light sources had been perfected, it was also done to help patients heal." ${ }^{23}$ Adjacency of neighbouring units has been considered in the articulation of windows to ensure privacy from one unit to another. This is denoted with red dashed lines on the units floor plans. The use

22 Dannenberg, Andrew L., Howard Frumkin, and Richard Jackson. Making Healthy Places: Designing and Building for Health, Well-being, and Sustainability. Washington, D.C.: Island, 2011. Print.

23 Sternberg, Esther M. Healing Spaces: The Science of Place and Well-being. Cambridge, MA: Belknap of Harvard UP, 2009. Print. 
of "sunlight and open windows were thought to be among the most effective means of purifying the air." 24 


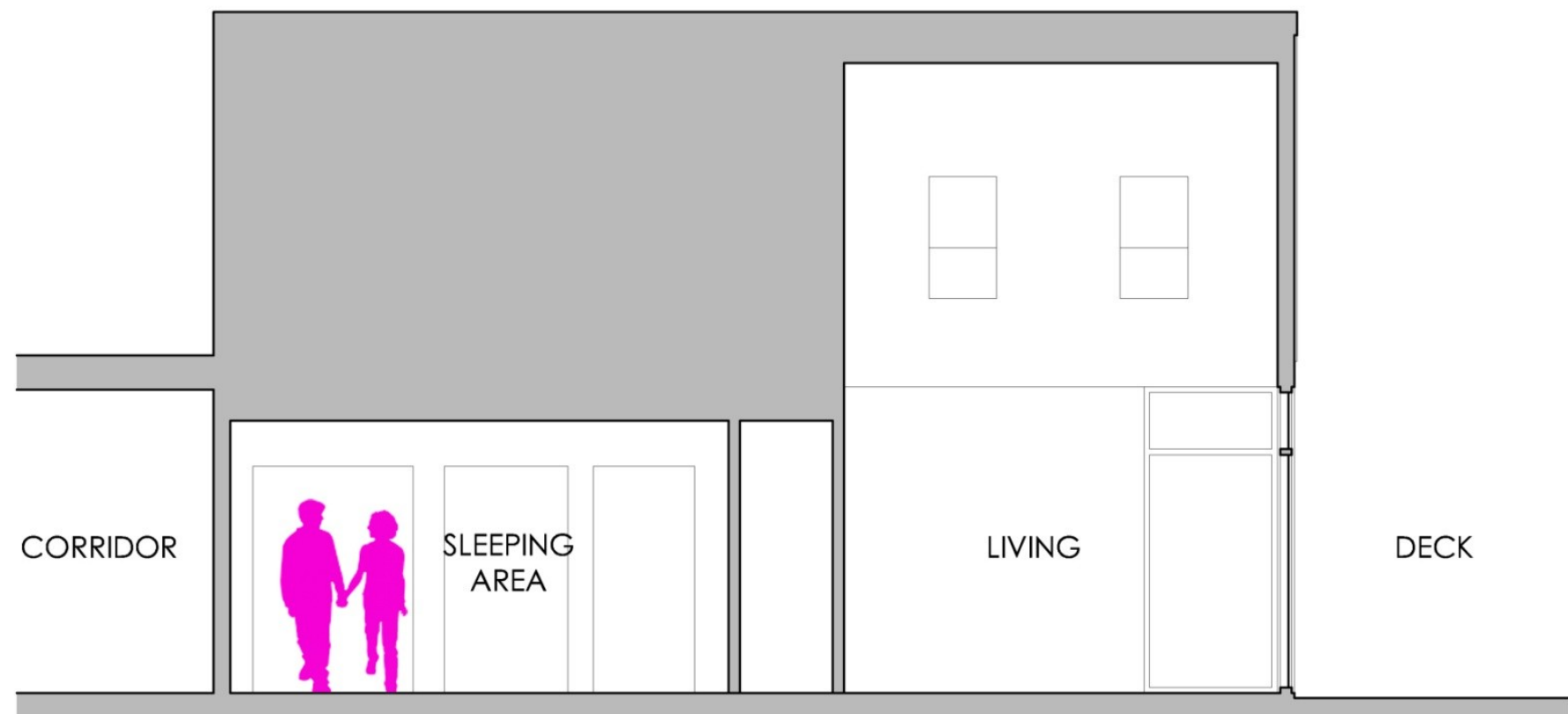

Figure 25: Section - Resident Unit 


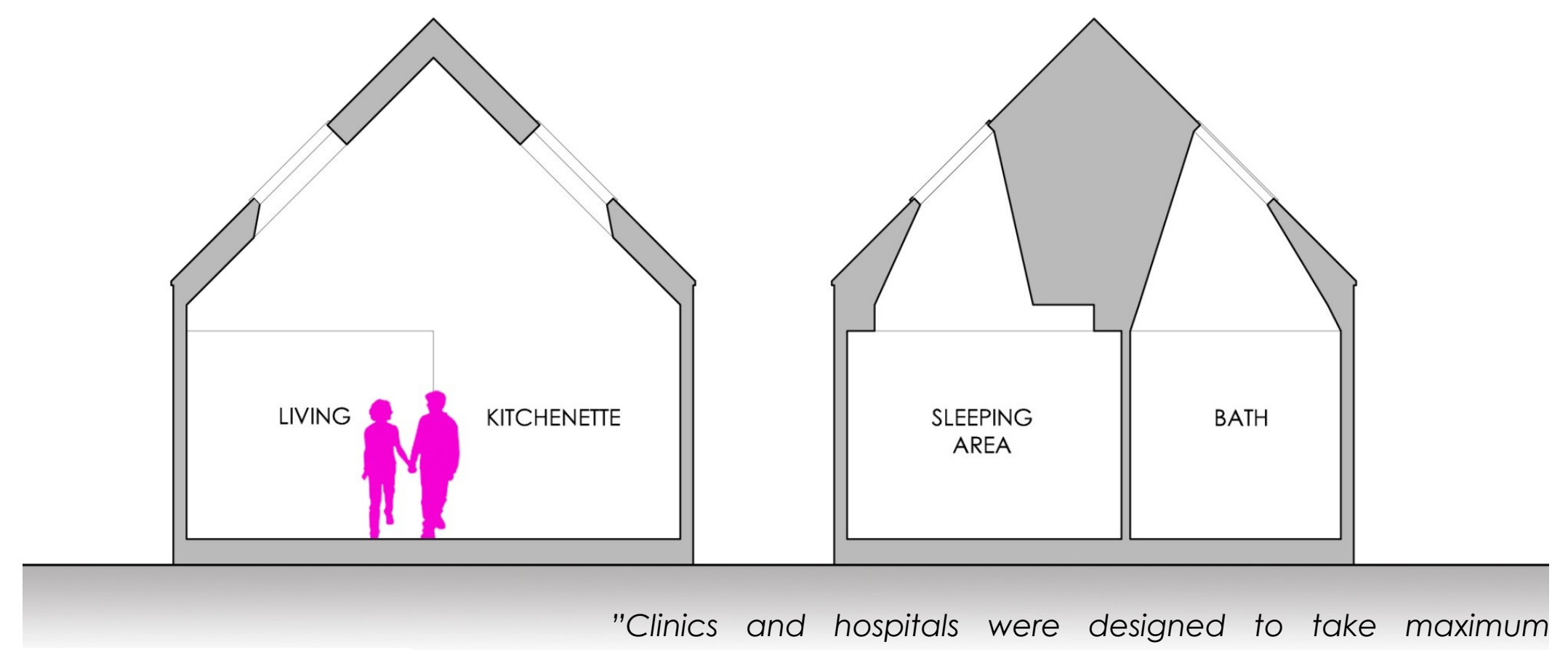

Figure 26: Section - Resident Unit advantage of available sunlight, with large windows facing south ... sunlight and open windows were thought to be among the most effective means of purifying the air." 25 


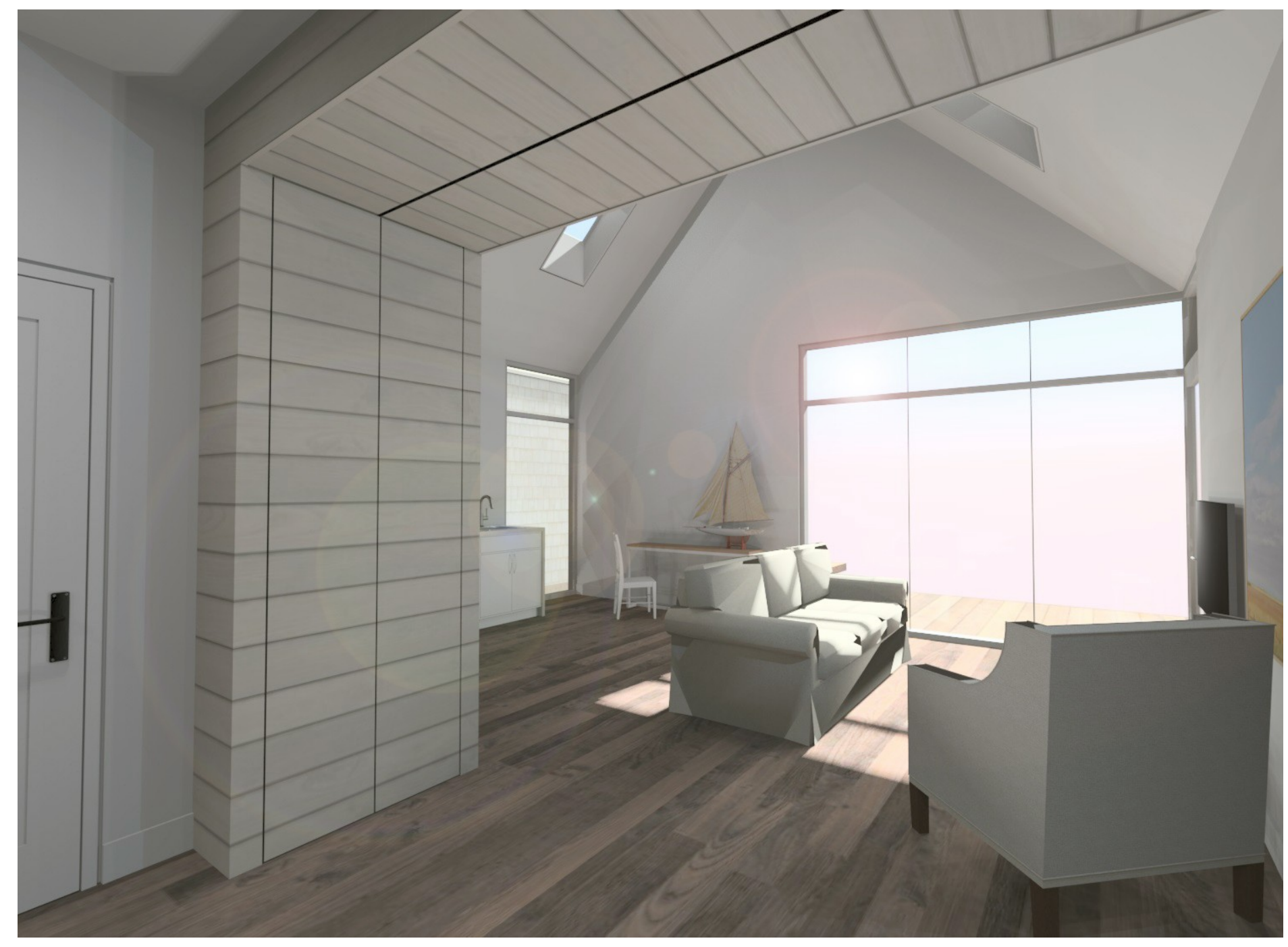

Figure 27: Interior view of resident unit. (Sleeping area towards living area) 


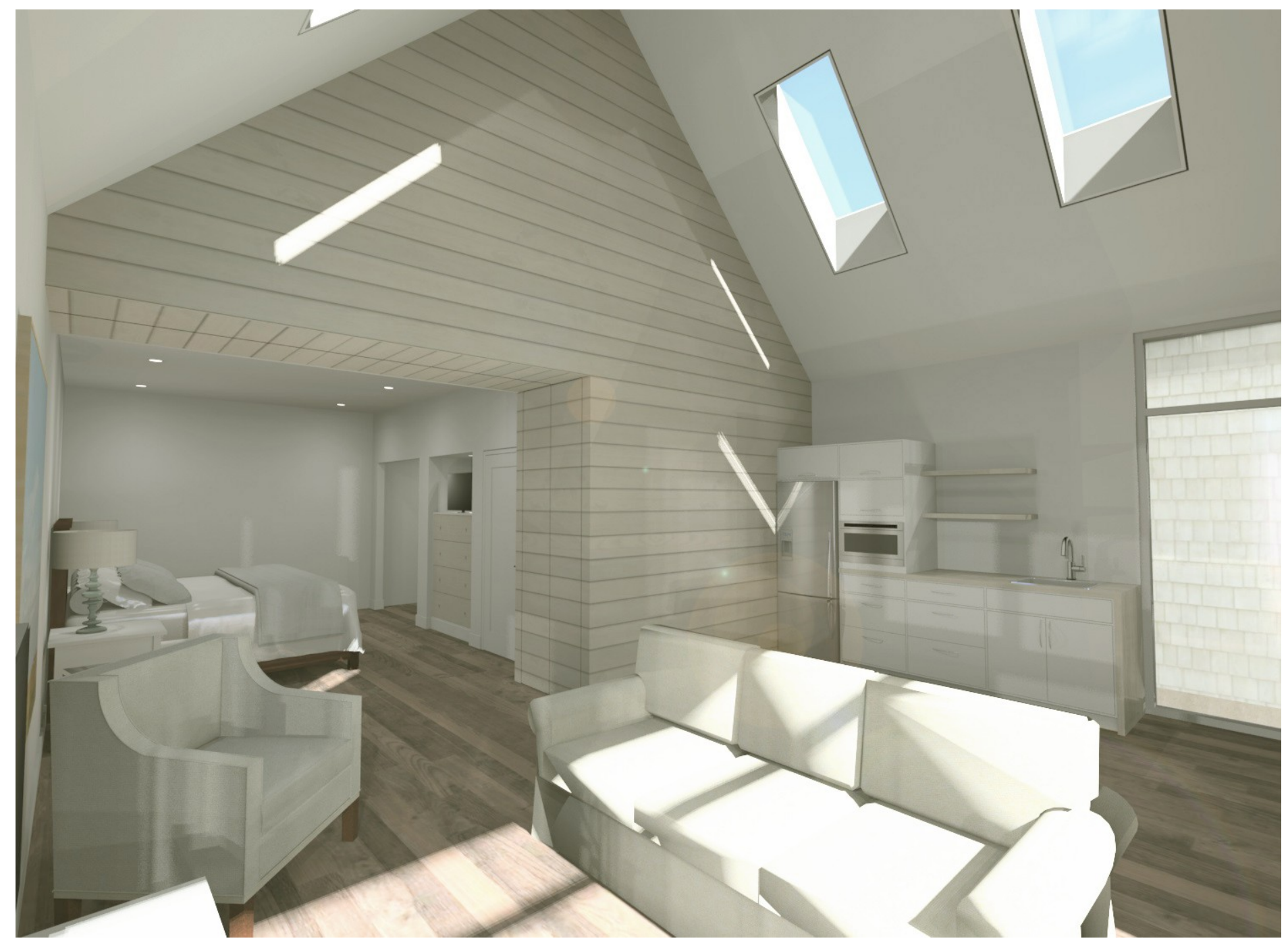

Figure 28: Interior view of resident unit. (Living area towards kitchenette and sleeping area) 


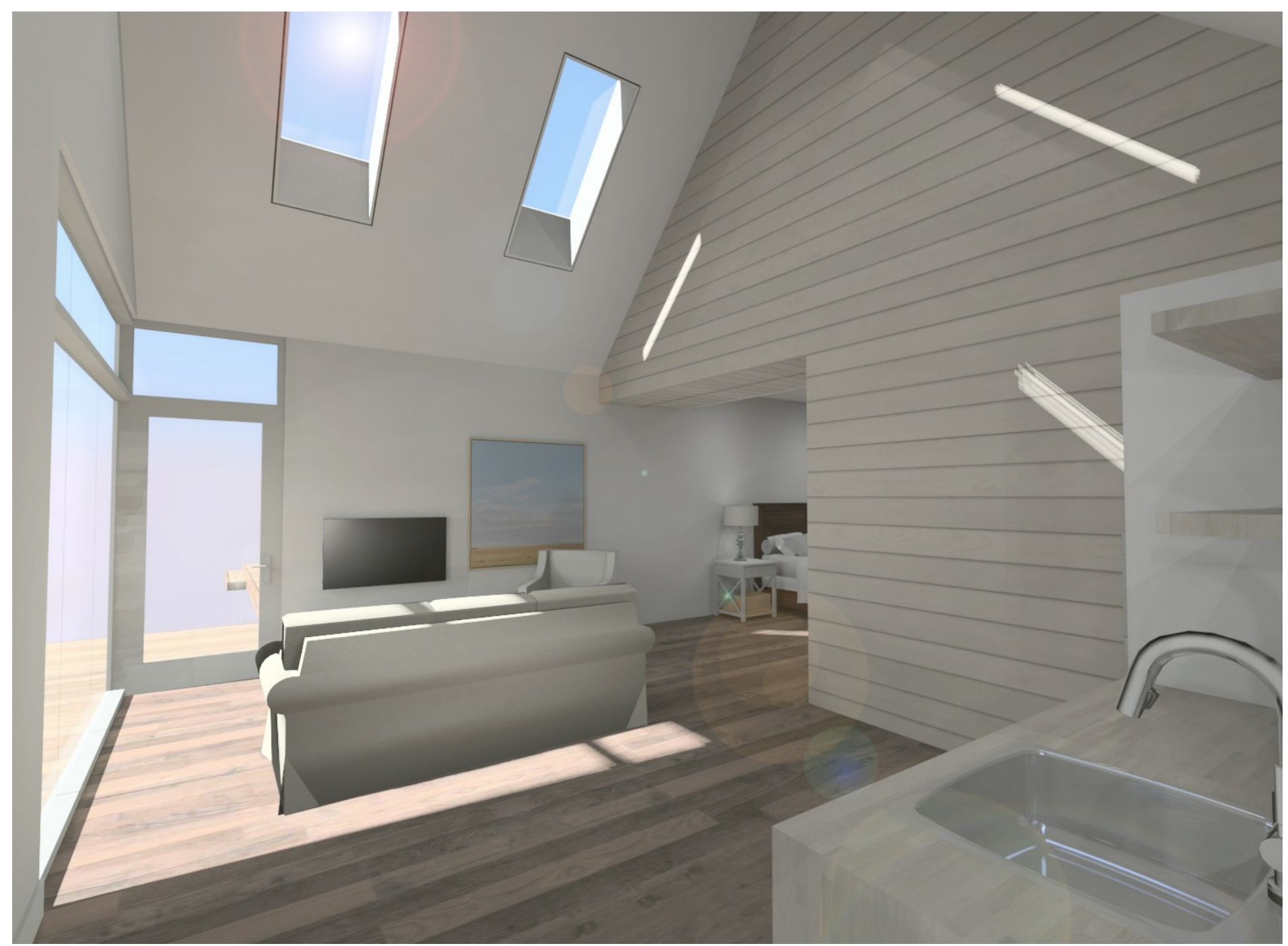

Figure 29: Interior view of resident unit. (Kitchenette towards living area and sleeping area) 


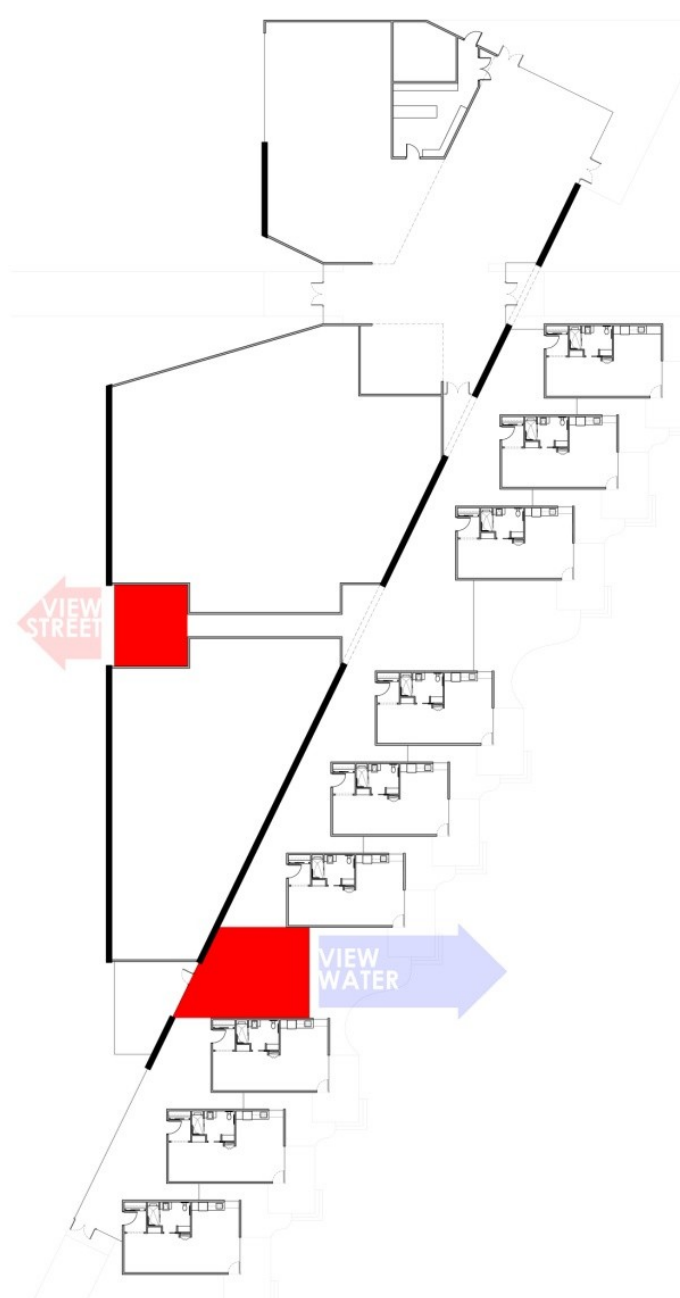

Figure 30: Key Plan: Resident lounge spaces. Street View + Water View

\section{Resident Lounge:}

Space for the residents to gather outside of their defined units is important to encourage communication and socializing for the residents. "Designers and planners can promote psychological health by creating places that are not noisy or crowded; that promote access to daylight; that encourage social interaction."26 To support this, two resident lounge spaces have been added to the program to encourage residents to leave their individual units and visit with other residents. The lounge spaces can also be used by family during their visits. One lounge is located on the street side of the main building to allow the residents to connect to what is going on surrounding the building without having to leave the building. The second lounge

26 Dannenberg, Andrew L., Howard Frumkin, and Richard Jackson. Making Healthy Places: Designing and Building for Health, Well-being, and Sustainability. Washington, D.C.: Island, 2011. Print. 
space is located waterside with views of the water and natural greenery. Both lounges share the characteristics of exterior floor to ceiling glazing to blur the definition of exterior to interior. 


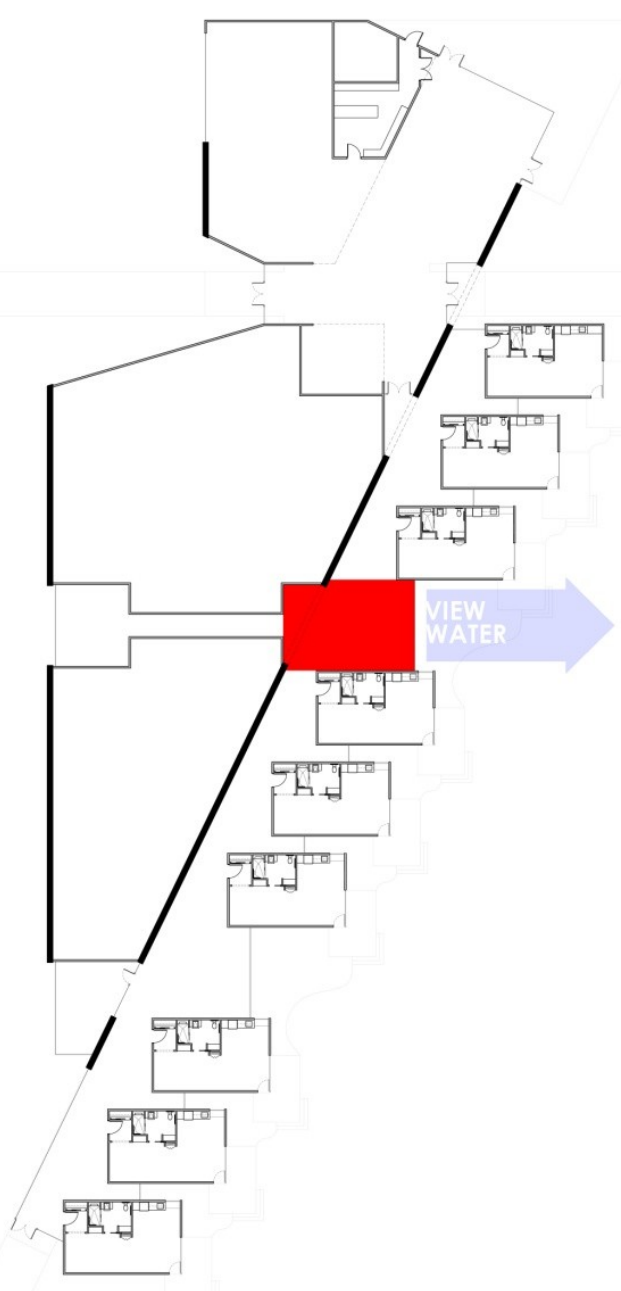

\section{Nurse Station:}

The nurse station has been centrally located on the waterside of the building with direct access to the units via the unit corridor. The nurse station is placed between two resident units along the exterior perimeter of the floor plan to allow an abundance of natural day lighting, and enjoyable water views. Dictated by the resident units requiring the greatest level of care, the nurse station has been offset to the north of the floor place for ease of unit access. The nurse station is centrally located amongst the building services for ease of access to medication, laundry and building storage. The location also allows for a watchful eye over the residents when they are outside.

Figure 31: Key Plan: Nurse Station 


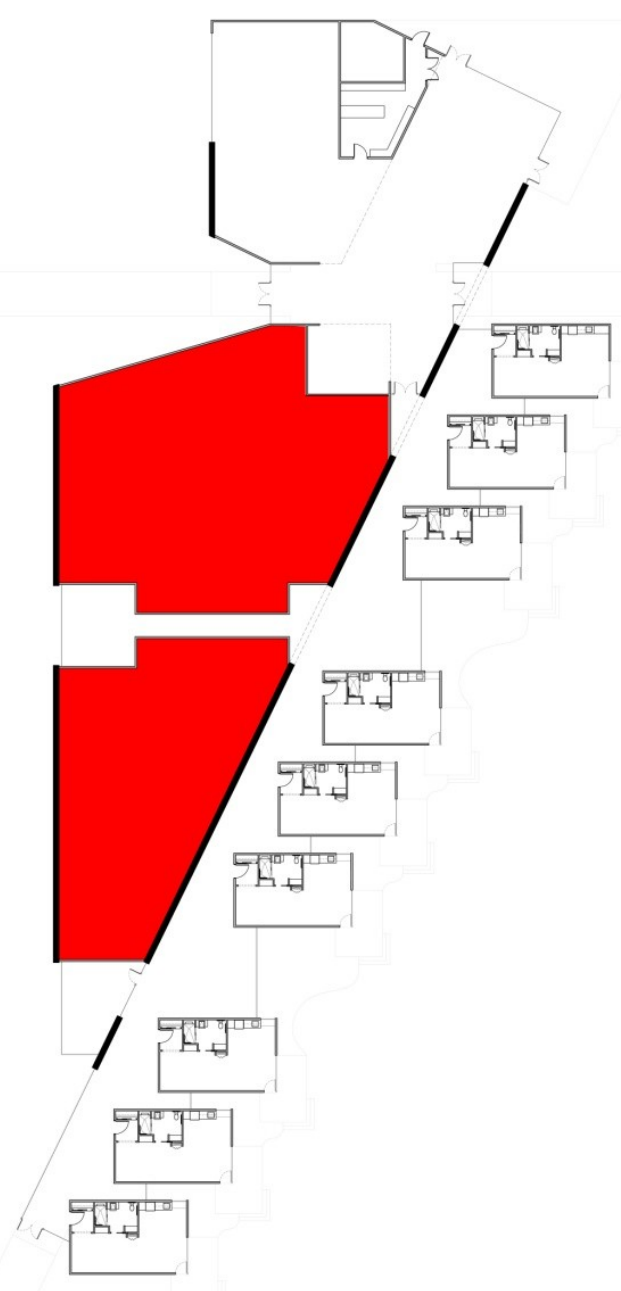

\section{Building Services:}

Behind the scenes, mechanical, electrical, laundry services, medication storage, facility management/administration, and building storage make up the facilities building services. Placed street side within the floor plan, the building services are easily accessible for equipment maintenance and daily deliveries. Setting the building services inland allows the resident units and the community/dining unobstructed views of the water.

Figure 32: Key Plan: Building Services. 


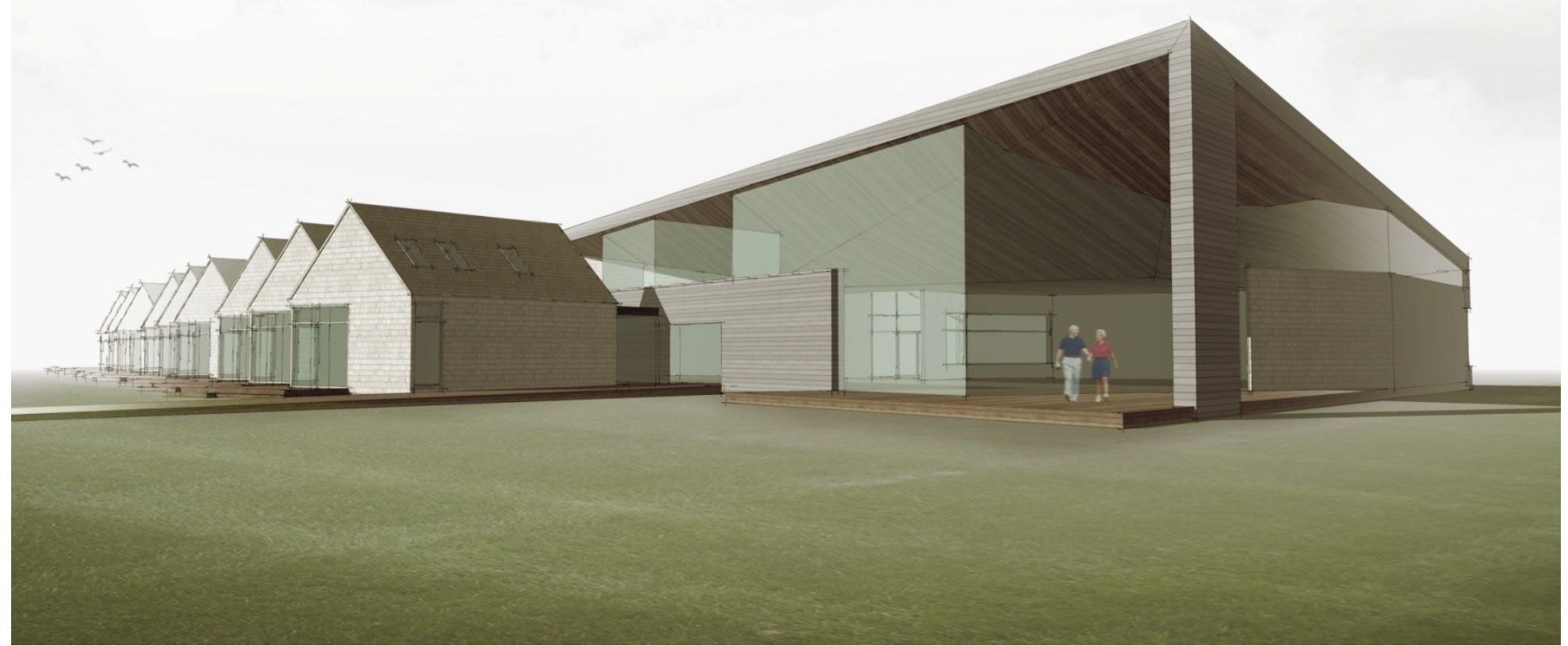

Figure 33: Building Perspective (Water Side) 


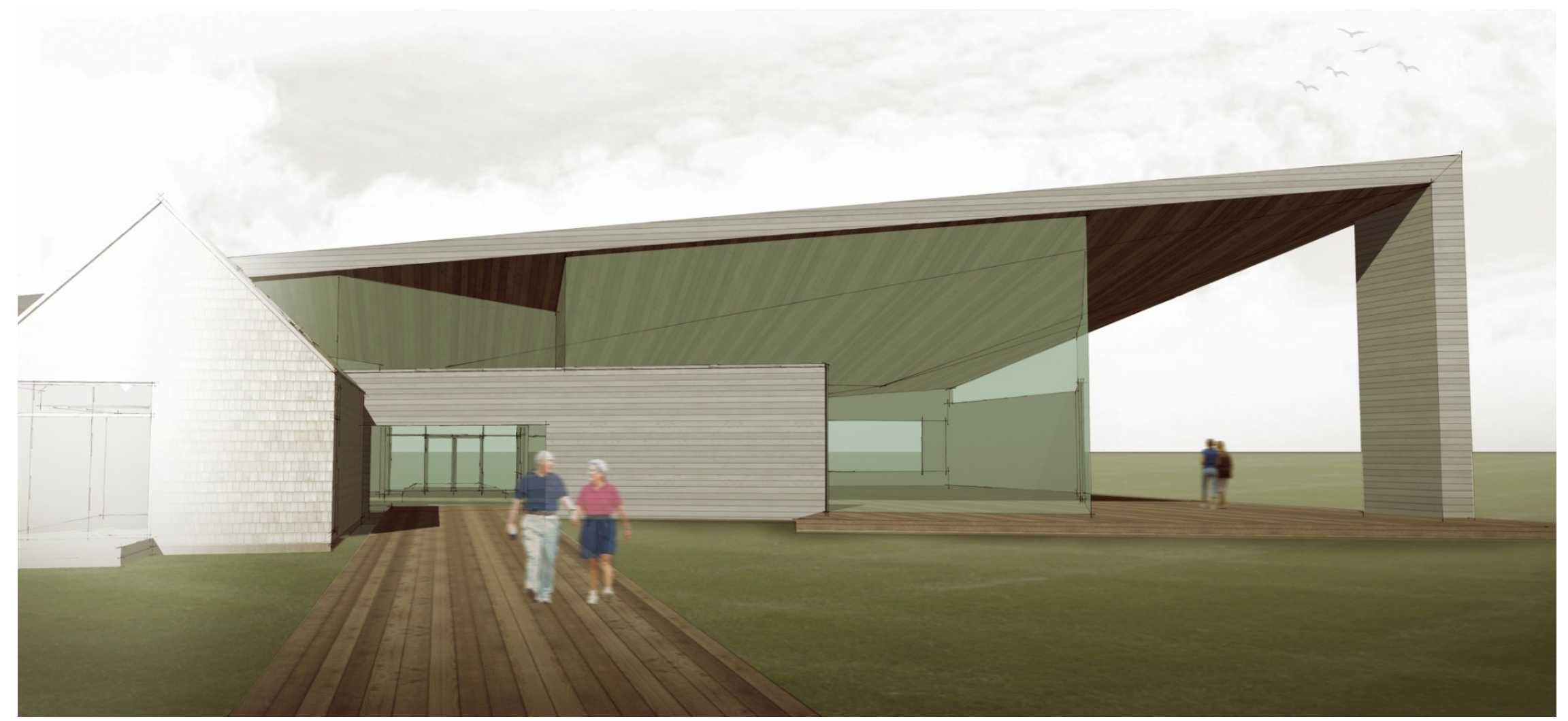

Figure 34: Building Approach (Water Side) 


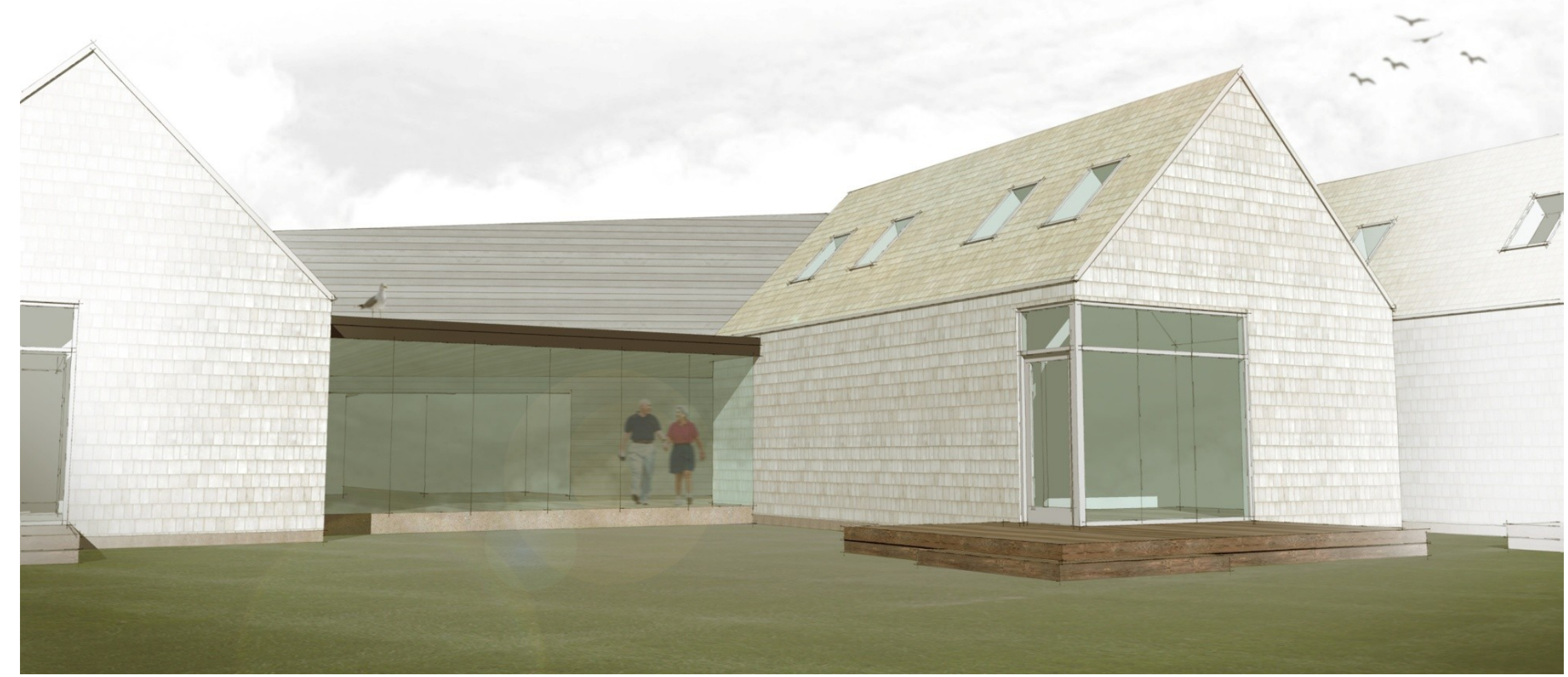

Figure 35: Building Perspective (Resident Unit/Lounge) 


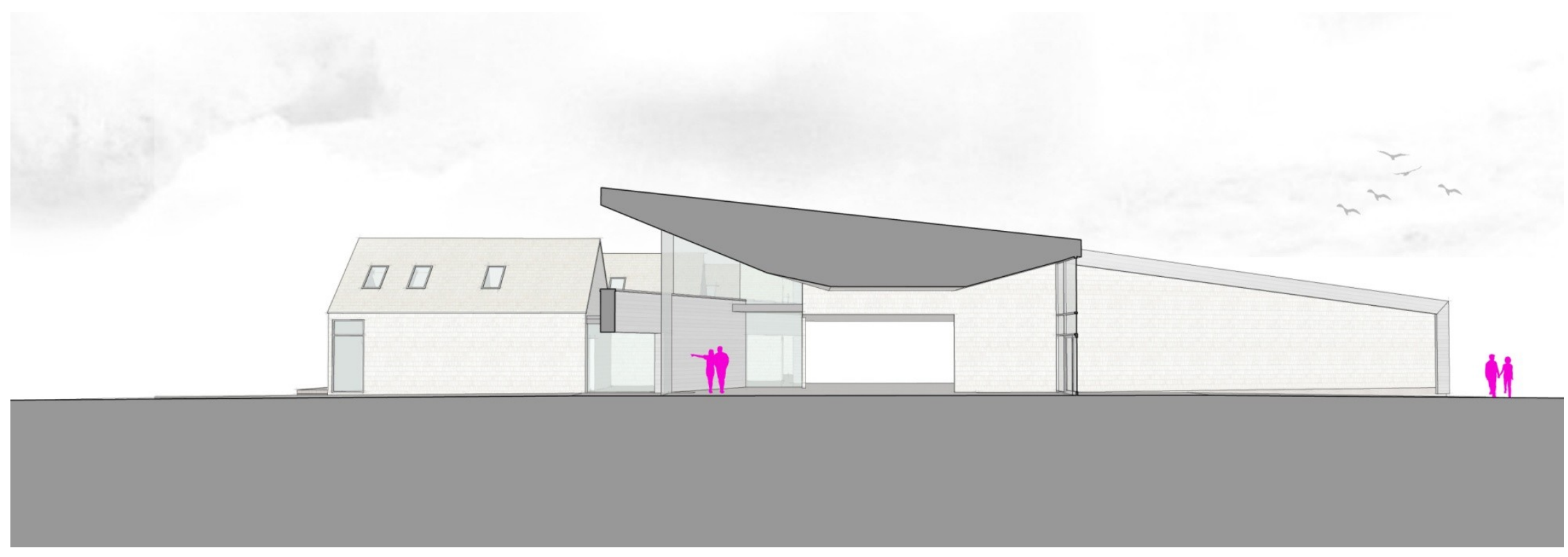

Figure 36: Building Section D 


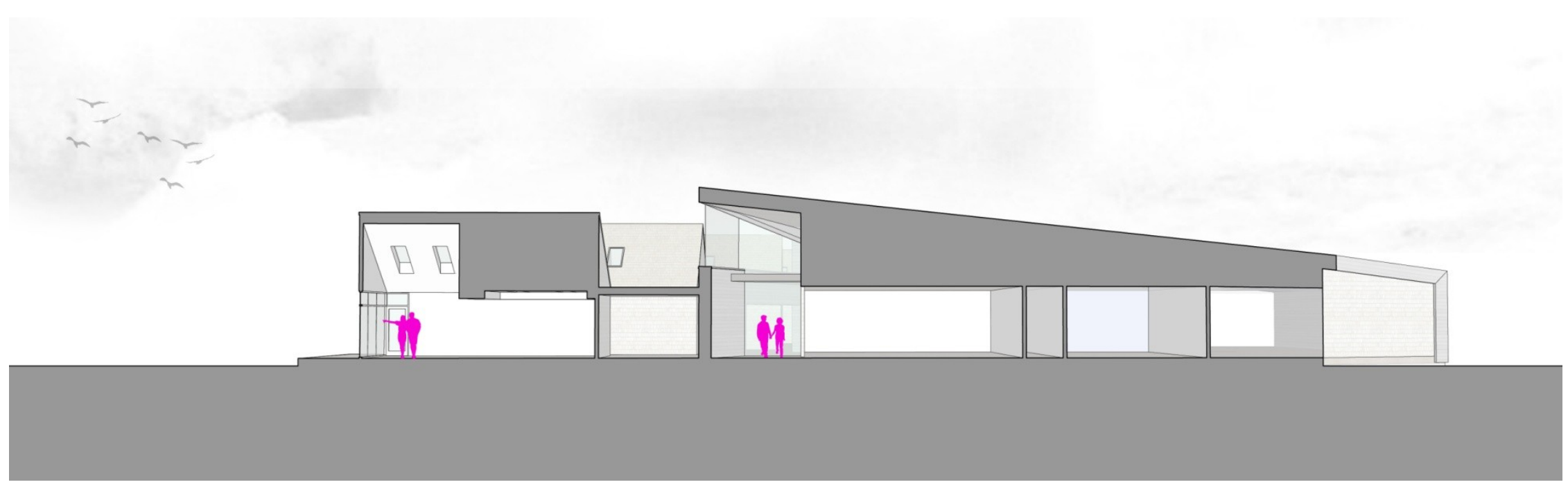

Figure 37: Building Section E 


\section{ALTERNATE BUILDING SECTION}

Design analysis with focus on today's construction costs on a square foot basis, requires a building footprint to be condensed and reduced where possible. Figure Diagram 38 provides example of how the proposed facility might be modified in section to allow for a reduction on building cost. The current design diagram illustrates three disconnected elements: the resident unit; part of which is 1.5 storeys in height, building circulation, and building services at one storey in height. The alternate building section allows the three elements to be condensed. The partial attic space above the sleeping area of the resident unit becomes home to a second storey of building service. Providing the second floor reduces the building footprint as illustrated by the dashed red line which denotes the 
extent of the current design. The circulation is also encompassed into the building service space.

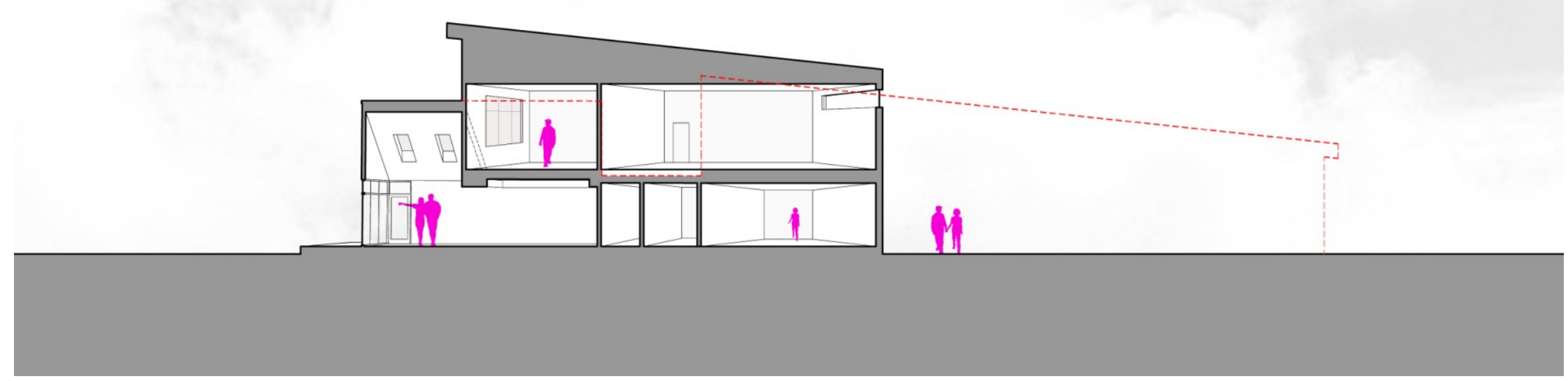

Figure 38: Alternate Building Section E 


\section{CONCLUSION}

Through investigation of the current Long-Term Care model on Prince Edward Island, I am compelled to argue change is needed. The current model does not reasonably value an individual's deep roots in community, routine, friends, and family. The centralized model of service is less than desirable for rural PEl. As Scandinavian countries have known for years, home care is the best care. Whereas, this is not always possible due to the medical conditions of the individual, a second option of care in their community needs to be offered. Smaller Long Term Care facilities would provide the medical care that is needed while respecting community and limiting the isolation that many seniors face when moving to centralized facilities. Allowing for several decentralized models across Prince Edward Island 
will assist in generating the sustainable revenue required to support rural communities. 


\section{BIBLIOGRAPHY}

Print:

Dannenberg, Andrew L., Howard Frumkin, and Richard Jackson. Making Healthy Places: Designing and Building for Health, Well-being, and Sustainability. Washington, D.C.: Island, 2011 . Print.

Knowles, Ralph L. Ritual House: Drawing on Nature's Rhythms for Architecture and Urban Design. Washington, DC: Island, 2006. Print.

Pallasmaa, Juhani. "Materiality and Time." The Eyes of the Skin: Architecture and the Senses. Chichester: Wiley-Academy, 2005. Print.

Sternberg, Esther M. Healing Spaces: The Science of Place and Wellbeing. Cambridge, MA: Belknap of Harvard UP, 2009. Print.

Web:

"Camp at Cabot Beach." Camp at Cabot Beach. N.p., n.d. Web. 12 Jan. 2015.

"Common Menu Bar Links." ARCHIVED. N.p., 02 Mar. 201 1. Web. 12 Feb. 2015. 
"Common Menu Bar Links." Home and Community Care. N.p., 01 Oct. 2004. Web. 22 Mar. 2015.

"Community, Basic Concepts of Sociology Guide." Community, Basic Concepts of Sociology Guide. N.p., n.d. Web. 19 Mar. 2015.

"Definition of Community in English:." Community. N.p., n.d. Web. 11 Mar. 2015.

"Définitions." Définitions. N.p., n.d. Web. 15 Feb. 2015.

"Elderly Care in Sweden." Sweden.se. N.p., n.d. Web. 31 Mar. 2015.

"Evolution in Senior Housing." American Architectural Foundation. N.p., 18 Feb. 2013. Web. 19 Apr. 2015.

"Health PEl: Long-term Care." Health PEl: Long-term Care. N.p., n.d. Web. 14 Feb. 2015.

"Health PEl: Prince Edward Home." Health PEl: Prince Edward Home. N.p., n.d. Web. 14 Feb. 2015.

"How to End the Senior Loneliness Epidemic." How to End the Senior Loneliness Epidemic. N.p., n.d. Web. 19 Mar. 2015.

"Long-term Care in Canada. Senior Care in Canada Information and Long Term Care Planning Canada - Information for Families, Caregivers, and Seniors on Care-Years Planning." Long-term Care in Canada. Senior Care in Canada Information and Long Term Care 
Planning Canada - Information for Families, Caregivers, and Seniors on Care-Years Planning. N.p., n.d. Web. 19 Mar. 2015.

"News." : Integrated Service Areas. N.p., n.d. Web. 18 Feb. 2015.

"Prince Edward Home - BGHJ Architects." BGHJ Architects. N.p., n.d. Web. 14 Oct. 2014. 